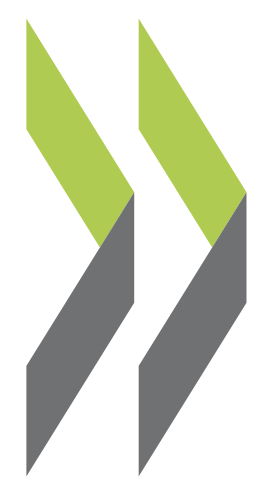

OECD Economics Department Working Papers No. 547

The Impact on Growth of Higher Efficiency of Public Spending on Schools 
Organisation de Coopération et de Développement Economiques

Organisation for Economic Co-operation and Development

27-Feb-2007

ECONOMICS DEPARTMENT

English - Or. English

THE IMPACT ON GROWTH OF HIGHER EFFICIENCY OF PUBLIC SPENDING ON SCHOOLS

Economics Department Working Paper No. 547

by Frédéric Gonand

All Economics Department Working Papers are available through OECD's internet web site at www.oecd.org/eco/Working_Papers 


\section{TABLE OF CONTENTS}

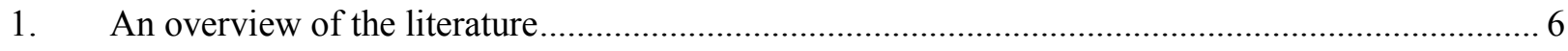

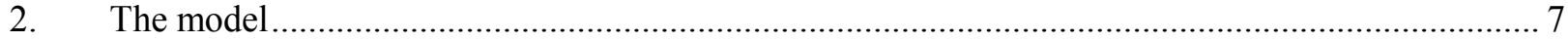

2.1 Assessing the impact of input-decreasing efficiency gains................................................ 7

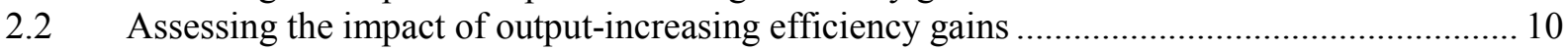

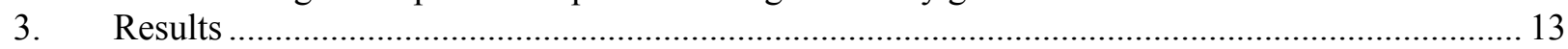

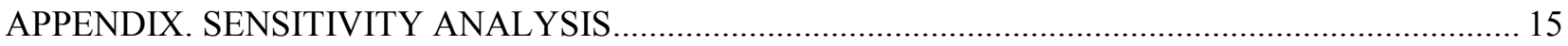

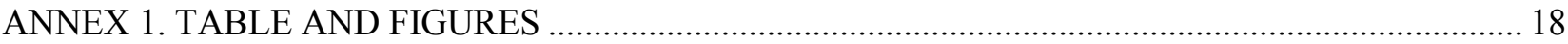

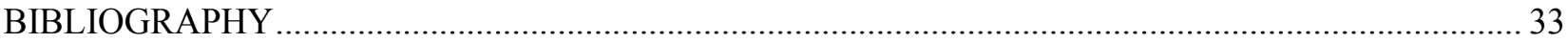

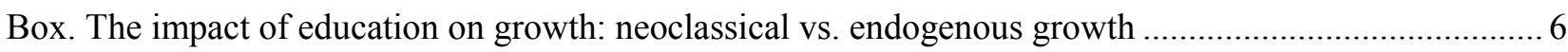




\section{ABSTRACT/RESUMÉ}

\section{The impact on growth of higher efficiency of public spending on schools}

This paper assesses the impact on economic growth of increased efficiency of public spending in primary and lower-secondary education. Higher efficiency in public spending in schools can bolster growth through two main channels. On the one hand, it can allow a transfer of labour from the public sector to the business sector at unchanged educational output. On the other, it can enhance educational output and productivity of the future labour force at unchanged public employment and expenditures. The paper argues that, in most cases, efficiency gains might have larger effects on GDP in the long run if they are used to increase educational outputs rather than to reduce inputs. A $10 \%$ increase on educational output might raise GDP by, on average, $3 \%$ to $6 \%$ in the long run in most OECD countries, whereas using efficiency gains to transfer resources to the business sector might have an impact of less than $1 \%$ on GDP. However, some trade-off can appear in the short run because input-decreasing efficiency gains materialise more rapidly on growth than improvements in output-increasing efficiency.

JEL Classification: H11; I20; I28.

Key words: Public spending efficiency; Public education; Structural reform; Long-run economic growth; Human capital.

\section{Effet sur la croissance d'un système éducatif primaire et secondaire plus efficace}

Ce document de travail évalue l'effet sur le PIB d'une efficacité accrue de la dépense publique dans le secteur de l'éducation primaire et secondaire. Une plus grande efficacité du système éducatif peut soutenir l'activité notamment grâce à des transferts d'effectifs du secteur public vers le secteur privé, ou une hausse de la performance des élèves et de leur productivité future à dépenses publiques inchangées. Cette étude montre que les gains d'efficacité se traduisent par des effets plus favorables sur le niveau du PIB à long terme dans la plupart des pays de l'OCDE s'ils renforcent la productivité future du travail que s'ils se traduisent par des réductions d'effectifs dans les écoles. Ainsi, une augmentation de $10 \%$ des performances des élèves à dépense publique inchangée augmenterait le niveau du PIB à long terme de $3 \%$ à $6 \%$ en moyenne, alors qu'une réduction de $10 \%$ des dépenses à connaissances des élèves inchangées ne soutiendrait l'activité à long terme que de $1 \%$ au plus. A court terme, un arbitrage peut cependant exister dans la mesure où les effets favorables sur la croissance liés à des transferts d'effectifs vers le secteur privé se matérialisent plus rapidement que l'augmentation graduelle de la productivité moyenne de la population active.

Classification JEL : H11 ; I20 ; I28.

Mots clés : Efficacité de la dépense publique; Education nationale; Réforme structurelle; Croissance à long terme ; Capital humain.

Copyright OECD, 2007.

Application for permission to reproduce or translate all, or part of, this material should be made to: Head of Publications Service, OECD, 2 rue André Pascal, 75775 Paris Cedex 16, France. 
ECO/WKP(2007)7 
ECO/WKP(2007)7

\title{
THE IMPACT ON GROWTH OF HIGHER EFFICIENCY OF PUBLIC SPENDING ON SCHOOLS
}

\author{
by Frédéric Gonand ${ }^{1}$
}

1. This paper assesses the impact on economic growth of increased efficiency of public spending in primary and lower-secondary education. Estimates of the possible efficiency gains can be found in Sutherland et al. (2007). Following the dichotomy adopted in that paper, higher efficiency can be used either to reduce inputs or to expand outputs. Thus, higher efficiency in public primary and secondary education (PSE) can bolster growth through two main channels. On the one hand, it can allow a transfer of labour from the public sector to the business sector, at unchanged educational output. On the other, it can enhance educational output and productivity of the labour force at unchanged public employment and expenditures. The latter effect will be referred to here as "output-increasing" efficiency whereas the former will be designed as "input-decreasing".

2. The paper argues that, in most cases, efficiency gains will have larger effects on GDP in the long run if they are used to increase educational outputs rather than to reduce inputs. A $10 \%$ increase on educational output from 2005 onwards -- roughly equivalent to increasing the average number of schooling years by 1 year at unchanged inputs -- raises GDP by, on average, 3\% to $6 \%$ in the long run. Using efficiency gains to transfer resources to the business sector has an impact of less than $1 \%$ on GDP. However, some trade-off can appear in the short run because input-decreasing efficiency gains materialise more rapidly on growth than improvements in output-increasing efficiency.

3. These estimates are intended to be illustrative and rely on a number of simplifying assumptions. As concerns the input-decreasing efficiency gains, the framework used in this paper does not account for the possible impact on growth of alternative public uses of lower spending in education, including a switch to other types of investment (e.g. infrastructure). The analysis also neglects the favourable dynamic supplyside effects of lower taxes on investment and labour supply -- though some sensitivity analysis suggests that the results might not be reversed should this mechanism be included in the model. As regards the output-increasing efficiency gains, the modelling assumes that all OECD countries can benefit from additional schooling years whereas, in reality, some of them may have reached a standard where there are diminishing returns. The paper also does not address the issue related to cross-country differences of rates of return on primary and lower-secondary education and provides estimates for different values of marginal returns for each country.

1. The author is a member of the Economics Department of the OECD. I am indebted to Michael Feiner, Jørgen Elmeskov, Robert Price, Isabelle Joumard, Douglas Sutherland, Chantal Nicq and other colleagues for their useful comments. I am also grateful to Paula Simonin for secretarial assistance. The opinions expressed in this paper are those of the author and are not necessarily shared by the OECD. 
4. The paper is organised as follows. Section 1 summarises the literature dealing with the empirical impact of education on growth, which is vast and still not consensual. Section 2 presents the framework developed in this paper to model and assess standard transmission mechanisms of higher efficiency of public spending in education to economic growth. Section 3 presents the results obtained and some conclusions.

\section{An overview of the literature}

5. Developments in growth theory since the 1990s owe much to the analysis of the impact of human capital on growth, triggering a flourishing empirical literature aimed at assessing this influence. The Box details the main characteristics of the debate that has recently developed about the impact of education on growth.

6. Over the recent past, some consensus among econometrical studies has slowly been emerging about the debate on the effects of education on growth (See Box). It suggests that the macroeconomic rate of return on education might be of the order of $3 \%$ to $6 \%$. This implies that an extra year of average schooling may raise output per capita by between $3 \%$ and $6 \%$ in the long run since the sample mean of average schooling is about ten years. This estimate remains cautious because it does not take account of possible transitory effects of longer education on the growth rate. Montanino et al. (2004) and De la Fuente and Ciccone (2003) suggest that an effect of longer education attributable to long-term technical progress gains might account for a further $3 \%$ of GDP in the long run.

\section{The impact of education on growth: neoclassical vs. endogenous growth}

As concerns the growth theory literature, recent neoclassical, Solow-type growth models typically encapsulate some proxy variable for the stock of human capital. Mankiw, Romer and Weil (1992) find good empirical support for this enlarged version of the production function. In this framework, a rise in human capital enhances the growth rate only temporarily. The long-run GDP growth rate is driven by population and technology only. However, empirically, separating the level effects of higher education on GDP (as suggested by the neoclassical theory) from possible impacts on the growth rate (as advocated by the endogenous growth theory) has proved very difficult.

Endogenous growth theory departs from the neoclassical setting insofar as it considers that education feeds into the stock of knowledge. Knowledge is seen as a particular type of capital which is less likely to encounter diminishing returns because it is non-rival and relatively non-excludable. In this framework, a rise in the level of education fostering the stock of knowledge may push up the growth rate permanently and not temporarily as in the neoclassical growth theory (Romer, 1990). The level of the stock of knowledge is assumed to affect the long-run GDP growth rate in a variety of ways, via the cumulation of ideas, inventions or the ability to adopt technology from abroad

The endogenous growth theory hypothesis can be tested econometrically by running panel regressions of the GDP growth rate on the level of human capital. Such a specification usually yields implausibly large orders of magnitude as regards the effect of education on activity (Hanushek and Kimko, 2000; Barro, 2001) (Table 1). These results are often hard to reconcile with past increases in the average years of schooling in OECD countries while potential growth has been declining over the long run.

Panel regressions more in line with the neoclassical theory assess the correlation between the GDP growth rate and the change in educational attainment (not the level). Benhabib and Spiegel (1994) as well as Pritchett (1996) both find a very weak correlation between the GDP growth rate and the change in educational attainment. However the recent literature considers that this result stems from measurement error (Krueger and Lindhal, 1999; de la Fuente and Domenech, 2000) and/or the use of data of poor quality (as argued in Steedman, 1996; or Bassanini and Scarpetta, 2001). The empirically blurred distinction between the level effect on GDP of longer education and a possible influence on its growth rate may result from technological diffusion. As advocated by De la Fuente and Ciccone (2003), an increase in human capital may trigger faster technological change. However this effect gradually disappears as the economy comes closer to the technological frontier where its TFP annual growth rate stabilises. Accordingly, the growth rate effect becomes a level effect over the medium or long run and, if convergence is sufficiently fast, the two effects can hardly be disentangled. 
7. The standard results of labour economics studies assessing the effect of higher education on wages and labour productivity are in line with this approximate range of 3\%-6\%. Following Mincer's (1974) seminal work, regressions of the wage of an individual on his/her number of years of schooling have shown that the private return of one additional year of education lies between $5 \%$ and $15 \%$ for most countries. For instance, Harmon et al. (2003) on EU data find that an extra year of schooling raises an individual's wage by around $8 \%$. Assuming that labour is paid its marginal productivity, this favourable effect on earnings reflects a similar positive impact on labour productivity. When multiplied by the labour share in GDP (i.e. around 0.7), these results are broadly in line with results from growth regressions.

8. The growth accounting literature is also helpful in this context. Growth accounting assesses the link between education and growth by disaggregating the labour force by levels of schooling. It then produces estimates of quality change in labour input, using data on the changing distribution of the workforce by educational attainment and mean income by education as weights (Griliches, 1997), and assumes that the relative wage is equal to the marginal productivity. In this framework, a rise in the education level bolsters labour productivity and thus growth. Jorgenson et al. (1987) find that the rise in the quality of the labour input in the United States between 1948 and 1979 may have accounted for about a fifth of the productivity residual that remains after accounting for the contribution of physical capital to growth. Griliches (1997) suggests that increases in educational attainment may have raised the growth rate by $0.2 \%$ or $0.3 \%$ since the 1970 s TFP slowdown. Overall, the growth accounting literature suggests that higher school attainment may have raised the annual GDP growth rate by between $0.2 \%$ and $0.5 \%$ over the recent past (see Table 1). As discussed above, these effects are transitional, driven by shifts in the educational composition of the labour force towards a new steady state.

9. Results of the growth accounting literature appear to be in line with the above-mentioned order of magnitude of $3 \%$ to $6 \%$ for the impact of an extra year of schooling on GDP. Assuming that the average number of schooling years has increased by 0.8 year over the past decade (Montanino et al., 2004), it suggests that the associated favourable impact on the growth rate would be between $0.2 \%$ and $0.5 \%$ per year on average -- as in Griliches (1997).

\section{The model}

10. This section presents a simple accounting methodology designed so as to capture the main mechanisms involved in relating higher efficiency in public spending in primary and lower-secondary education (PSE) to growth. Sensitivity analysis is performed in order to check that the orders of magnitude obtained are reasonably robust to the parameterisation (see Appendix). Two frameworks are constructed that assess the effect on economic activity of higher efficiency based on whether it is input-decreasing or output-increasing. In both cases, the GDP level increases while its long-run growth rate remains unchanged. The possible maximum increase in both types of efficiency, for each country, is computed by Sutherland et al. (2007) using a distance function methodology.

\subsection{Assessing the impact of input-decreasing efficiency gains}

11. In the case of input-decreasing efficiency gains, two mechanisms bolster the level of production of the business sector:

- The first channel relates to the increase in business employment due to the shift of resources to the private sector. This level effect enhances the production of the business sector. 
Table 1. Empirical studies assessing the link between the level of education and economic growth

\begin{tabular}{|c|c|c|c|c|}
\hline Authors & Data & Methodology & Proxy of human capital & Results \\
\hline $\begin{array}{l}\text { Mankiw, Romer and } \\
\text { Weil (1992) }\end{array}$ & $\begin{array}{l}98 \text { countries, } \\
1960-1985\end{array}$ & Growth regression & $\begin{array}{l}\text { Average fraction of the } \\
\text { population of working } \\
\text { age that is in secondary } \\
\text { school over } 1960-1985\end{array}$ & $\begin{array}{l}\text { The elasticity of GDP per capita with respect to human capital } \\
\text { is } 0.66 \text {. }\end{array}$ \\
\hline $\begin{array}{l}\text { Hanushek and Kimko } \\
\text { (2000) }\end{array}$ & $\begin{array}{l}31 \text { countries, from the } \\
1960 \text { s on }\end{array}$ & Growth regression & $\begin{array}{l}\text { Average years of } \\
\text { schooling + quality of } \\
\text { education: from test } \\
\text { scores }\end{array}$ & $\begin{array}{l}\text { An increase of one standard deviation in school attainment } \\
\text { raises the GDP per capita growth rate by } 0.26 \% \text { per year. An } \\
\text { increase of one standard deviation in mathematics and science } \\
\text { skills raises the GDP per capita growth rate by } 1.4 \% \text { per year. }\end{array}$ \\
\hline Barro (2001) & $\begin{array}{l}\text { Around } 100 \text { countries, } \\
1965-1995\end{array}$ & Growth regression & $\begin{array}{l}\text { Average years of school } \\
\text { attainment for male at } \\
\text { the secondary and } \\
\text { higher levels + science } \\
\text { tests scores }\end{array}$ & $\begin{array}{l}\text { An increase of one standard deviation in school attainment } \\
\text { (roughly one more year of education) raises the GDP per capita } \\
\text { growth rate between } 0.2 \% \text { and } 0.44 \% \text { per year. An increase of } \\
\text { one standard deviation in science tests scores (roughly equal in } \\
\text { this model to an increase of } 15 \% \text { in test scores) raises the GDP } \\
\text { per capita growth rate by } 1 \% \text { per year. }\end{array}$ \\
\hline $\begin{array}{l}\text { Bassanini and } \\
\text { Scarpetta (2001) }\end{array}$ & $\begin{array}{l}21 \text { OECD countries, } \\
1971-1998\end{array}$ & Growth regression & $\begin{array}{l}\text { Average years of } \\
\text { schooling }\end{array}$ & $\begin{array}{l}\text { One additional year of education raises the level of output per } \\
\text { capita by about } 6 \% \text { in the long run. }\end{array}$ \\
\hline $\begin{array}{l}\text { Jorgenson, Gollop } \\
\text { and Fraumeni (1987) }\end{array}$ & USA 1948-1979 & Growth accounting & & $\begin{array}{l}\text { A favourable shift in labour quality (education) accounts for a } \\
\text { fifth of the productivity residual of the aggregate production } \\
\text { function. }\end{array}$ \\
\hline Maddison (1991) & $\begin{array}{l}\text { FRA, DEU, USA, } \\
\text { JPN, GBR, NDL }\end{array}$ & Growth accounting & & $\begin{array}{l}\text { Changes in the quality of the labour force added on average } \\
\text { between } 0.1 \% \text { and } 0.5 \% \text { to annual growth rates between } 1950 \\
\text { and } 1984 .\end{array}$ \\
\hline $\begin{array}{l}\text { Englander and } \\
\text { Gurney (1994) }\end{array}$ & $\begin{array}{l}\text { G7 from the } 1960 \text { s to } \\
\text { the } 1980 \text { s }\end{array}$ & Growth accounting & & $\begin{array}{l}\text { Growth of the human capital accounts for a tenth to a fifth of } \\
\text { growth in total output on average. }\end{array}$ \\
\hline Griliches (1997) & USA & Growth accounting & & $\begin{array}{l}\text { Educational improvements in the US labour force may have } \\
\text { accounted for about } 0.2 \%-0.3 \% \text { per year of GDP growth rate } \\
\text { over recent decades. }\end{array}$ \\
\hline $\begin{array}{l}\text { de la Fuente and } \\
\text { Ciccone (2003) }\end{array}$ & \multicolumn{2}{|c|}{ Survey of the available empirical literature } & $\begin{array}{l}\text { Average years of } \\
\text { schooling }\end{array}$ & $\begin{array}{l}\text { The elasticity of output with respect to average years of } \\
\text { schooling can be expected to lie between } 0.4 \text { and } 0.54 \text {. }\end{array}$ \\
\hline
\end{tabular}


- The second channel relates to the productivity growth differential between the public and the private sector. Productivity gains are structurally lower in public education than in businesses on average at the aggregate level. While empirical research is still coping with measurement problem on this issue, structural productivity gains in public education can reasonably be assumed to range between $-1 \%$ to $+0.5 \%$ per year, much lower than $+1.5 \%$ on average in the business sector. ${ }^{2}$ In this context, shifting teachers from the public to the private sector increases the level of efficient labour units in the economy further and thus the GDP level.

12. The impact on growth of input-decreasing efficiency gains in public schools is assessed by comparing the level of GDP if a reform is implemented (from 2005 on) with the same level in a noreform, baseline scenario. The framework used basically aims at simulating the labour force in efficient units up to 2050 , with the structure of cohorts by educational attainment, the participation and the unemployment rates by age-groups frozen on the simulation period.

13. Formally, the impact on the level of GDP in country $j$ at year $t$ of a rise in input-decreasing efficiency from 2005 onwards is noted $\left(G_{t, j}^{\text {input }}\right.$ ) and computed as the increase in efficient labour units in the business sector allowed by the shift of teachers from the public to the business sector multiplied by the share of labour in the value added, such as:

$$
G_{t, j}^{i n p u t}=\delta_{j} \frac{\left(N_{0, t, j} \lambda_{0, j}+\sum_{a=1}^{8} N_{a-1, t-1, j} \lambda_{a-1, j}\right) \varphi_{j}\left(1+\gamma_{p r i v}-\gamma_{p u b}\right)^{5} \alpha_{j}}{L_{t, j}}
$$

where:

- $\delta_{j}$ stands for the share of labour in the value added of the business sector in country $j$,

- $\quad N_{a, t, j}$ refers to the population of the age-group $a$ at year $t$ in country $j$. Demographic simulations providing with the $N_{a, t, j}$ 's use national assumptions and a demographic model (Gonand, 2005). The value of $a$ is set to 0 for an individual aged 20 to 24, to 1 for an individual aged 25 to 29 and so on until age-group $a=8$ for individuals between 60 and 64 . The possible values for parameter $t$ are $\{2000 ; 2005 ; \ldots ; 2050\}$.

- $\quad L_{t, j}$ stands for business employment at year $t$ in country $j$. Simulations of future total business employment assume that the employment rates by age-groups are frozen from 2005 on.

- the parameter $\lambda_{a, j}$ refers to the employment rate of the age-group $a$ in country $j$.

- $\varphi_{j}$ is the ratio (total number of teachers / total employment) in country $j$. When multiplied by future total employment, it allows for simulating the future population of teachers. Simulations of the future population of teachers in a no-reform scenario assume that the ratio (total number of teachers / total employment) in country $j$ is frozen from 2005 on.

2. See UK Department for Education and Skills (2005), Beudaert (2004) on French data or Collesi (2000) on Italian data. More details are given in the Appendix. 
- the parameter $\gamma_{\text {priv }}$ refers to the annual structural gains of labour productivity in the business sector and $\gamma_{p u b}$ to the annual structural change of labour productivity in public education. Annual TFP gains in the private sector $\left(\gamma_{\text {priv }}\right)$ are assumed to be $1.5 \%$. Structural productivity changes in the public sector $\left(\gamma_{p u b}\right)$ are assumed to be nil, in line with the available literature (see Appendix for sensitivity analysis).

- $\alpha_{j}$ stands for the possible rise in input-decreasing efficiency gains in public spending in education in country $j$ from 2005 on (in \%), as computed by Sutherland et al.(2007).

14. In this framework, the impact on the level of GDP of a given gain in input-decreasing efficiency depends positively on the initial number of teachers relative to private employment, the productivity differential between the public and the private sector and the share of labour in the value added of the business sector.

\subsection{Assessing the impact of output-increasing efficiency gains}

15. Output-increasing efficiency gains in public spending in primary and lower-secondary education bolster labour productivity in the private sector and thus GDP because they enhance the stock of human capital at unchanged public expenditures. This effect materialises gradually over time, with better trained, relatively more productive cohorts progressively replacing older, less educated retiring generations. Accordingly, the effect on the level of GDP of higher output-oriented efficiency in public expenditure rises gradually before stabilising around 2040, when all current cohorts will have retired.

16. The favourable impact on the GDP level is computed as the increase in efficient labour units in the private sector allowed by the rise in educational output and human capital, multiplied by the share of labour in the value added of the business sector.

17. Formally, the impact on the level of GDP at year $t$ in country $j$ of a permanent rise in outputincreasing efficiency in PSE spending from 2005 onwards is noted $\left(G_{t, j}^{\text {output }}\right)$ and computed as the increase in efficient labour units in the private sector allowed by the rise in educational output, multiplied by the share of labour in the value added of the business sector:

$$
G_{t, j}^{\text {output }}=\delta_{j}\left(\frac{\sum_{a=0}^{8} N_{a, t, j} e_{a, j}\left[\omega_{a, t, j}^{*} E_{a, t, j}^{P S E}+\omega_{a, t, j}^{\prime} \lambda_{u p \mathrm{sec}, j} E_{a, t, j}^{u p \mathrm{sec}}+\omega_{a, t, j}^{\prime} \lambda_{\text {tertiary }, j} E_{a, t, j}^{\text {tertiary }}\right]}{\sum_{a=0}^{8} N_{a, t, j} e_{a, j}\left[\omega_{a, t, j} E_{a, t, j}^{P S E}+\omega_{a, t, j} \lambda_{u p \mathrm{sec}, j} E_{a, t, j}^{u p \sec }+\omega_{a, t, j} \lambda_{\text {tertiary }, j} E_{a, t, j}^{\text {tertiary }}\right]}-1\right)
$$

where the numerator measures the business employment in efficient labour units if an output-increasing reform is implemented, and the denominator the same variable if no-reform is implemented.

- $\delta_{j}$ stands for the share of labour in the value added of the business sector in country $j$,

- $\quad N_{a, t, j}$ refers to the population of the age-group $a$ at year $t$ in country $j$. The value of $a$ is set to 0 for an individual aged 20 to 24 , to 1 for an individual aged 25 to 29 and so on until age-group $a=8$ for individuals between 60 and 64. The possible values for parameter $t$ are $\{2000 ; 2005 ; \ldots ; 2050\}$.

- the parameter $e_{a, j}$ refers to the employment rate in the business sector of the age-group $a$ in country $j$. 
- $\quad E_{a, t, j}^{P S E}, E_{a, t, j}^{u p \text { sec }}$ and $E_{a, t, j}^{\text {tertiary }}$ stand for the fraction of the employed population of the age-group $a$ in the business sector at year $t$ in country $j$ whose educational attainment is respectively lower secondary, upper secondary, and tertiary. By definition, $E_{a, t, j}^{P S E}+E_{a, t, j}^{u p \sec }+E_{a, t, j}^{\text {tertiary }}=1$.

- the parameter $\omega_{a, t, j}$ stands for the endowment in efficient labour unit for an individual of agegroup $a$ in the private sector at year $t$ in country $j$ with lower-secondary education, in the noreform scenario. The value of $\omega_{a, t, j}$ in 2000 for a worker aged 20-24 is normalized to 1, thus $\omega_{0,2000, j}=1$. It increases thereafter along with productivity gains: $\omega_{a+1, t+1, j}=\omega_{a, t, j}\left(1+\gamma_{p r i v}\right)^{5}$.

- the parameters $\lambda_{u p \mathrm{sec}, j}>0$ and $\lambda_{\text {tertiary }, j}>0$ stand for the endowments in efficient labour unit relative to $\omega_{a, t, j}$ for individuals of age-group $a$ in country $j$ with upper-secondary (resp. tertiary) education. They are obtained from OECD (2006), Education at a Glance which gives wages by level of educational attainment.

- $\omega_{a, t, j}^{*}$ stands for the endowment in efficient labour unit if a reform is implemented, for individuals with lower-secondary education working in the business sector in year $t$ and in country $j$. If output-increasing efficiency gains occur from 2005 on, this endowment is higher than in the no-reform scenario (i.e., $\left.\omega_{a, t, j}\right)$. For instance, in the case of young individuals leaving schools in $2005(a=0)$ and joining the labour market in the private sector in country $j$ with a lower-secondary educational attainment, one has: $\omega_{0,2005, j}^{*}>\omega_{0,2005, j} \cdot \omega_{a, t, j}^{*}$ increases over time in line with productivity gains, thus $\omega_{a+1, t+1, j}^{*}=\omega_{a, t, j}^{*}\left(1+\gamma_{p r i v}\right)^{5}$.

- Output-increasing efficiency gains in the PSE system might also enhance the productivity of young individuals entering the labour market with higher than PSE educational attainment $\left(\omega_{0, t, j}^{\prime} \geq \omega_{0, t, j}\right)$. In an upper-bound case, the productivity gains of individuals with higher than PSE education is assumed to be equal to the productivity gains of workers with lowersecondary education (thus $\omega_{0,2005, j}^{\prime}=\omega_{0,2005, j}^{*}$ in expression (2)). A lower-bound case corresponds to the absence of any effect of enhanced efficiency in PSE on the productivity of young workers with higher education $\left(\omega_{0,2005, j}^{\prime}=\omega_{0,2005, j}\right)$. To overcome the difficulties in assigning relative importance between these two polar scenarios, the approach adopted here is based on random weights, as applied in previous OECD studies constructing institutional indicators (see Appendix). ${ }^{3}$

3. This technique uses 1000 sets of randomly generated weights for each of the two scenarios envisaged (i.e. $\omega_{0,2005, j}^{\prime}=\omega_{0,2005, j}^{*}$ and $\left.\omega_{0,2005, j}^{\prime}=\omega_{0,2005, j}\right)$ to calculate 1000 values of $G_{t, j}^{\text {output }}$. The random weights are drawn from a uniform distribution between 0 and 1 and normalised so as to sum to 1 . This is equivalent to assuming complete uncertainty about the most appropriate value of the weights associated to the scenarios. Accordingly, the resulting distribution of $G_{t, j}^{\text {output }}$ reflects the possible range of values given no a priori information on the most appropriate value for each of the weights. $80 \%$ confidence intervals are calculated from these distributions. 
18. The variable $\omega_{0,2005, j}^{*}$, which stands for the endowment in efficient labour unit of young workers with lower-secondary education if a scenario of output-increasing efficiency gains, is in turn computed as:

$$
\omega_{0,2005, j}^{*}=\omega_{0,2005, j}\left(1+\beta_{j} \bar{y}_{2005, j} \mu\right)
$$

where $\beta_{j}$ stands for the output-oriented efficiency gains in public spending in primary and lowersecondary education (in \%), $\bar{y}_{2005, j}$ refers to the average number of schooling years in primary and lower-secondary education in country $j$ in 2005 , and $\mu$ corresponds to the effect on wage of one additional year of education.

19. This relation relies on the following intuitions and assumptions:

- a $\beta_{j} \%$ increase in output-oriented efficiency gains translates into a $\beta_{j} \%$ increase in average PISA scores in country $j$.

- a $\beta_{j} \%$ increase in average PISA scores in country $j$ is equivalent to an increase in the average number of schooling years in primary and lower-secondary education $\left(\bar{y}_{2005, j}\right)$ in country $j$ equal to $\beta_{j} \bar{y}_{2005, j}$ years. $^{4}$

- $\quad$ an increase in the average number of PSE schooling years of $\left(\beta_{j} \bar{y}_{2005, j}\right)$ translates into a favourable impact on the wage of individuals with PSE of $\left(\beta_{j} \bar{y}_{2005, j} \mu\right)$ (in \%). Provided that labour is paid its marginal productivity, this $\left(\beta_{j} \bar{y}_{2005, j} \mu\right) \%$ increase in wage reflects an identical rise in productivity and efficient labour endowment.

20. The parameterisation of the model is mostly based on data from Education at a Glance. ${ }^{5}$ The value of the share of labour in the value added of the business sector in country $j$ (noted $\delta_{j}$ here) is set at $70 \%$ for all countries.

21. In this framework, the impact on growth of a given rise in output-increasing efficiency in public schools depends positively on the private rate of return on education, the fraction of the population with only primary and lower-secondary educational attainment and the share of labour in the value added. Assuming that a more output-efficient PSE system may also bolster the productivity of individuals with higher educational attainment, the impact on growth of a given rise in output-increasing efficiency in public schools can also be positively influenced by the productivity differential between workers with higher education and workers with only primary and lower-secondary educational attainment.

4. Since the average number of schooling years in primary and lower-secondary education $\left(\bar{y}_{2005, j}\right)$ is close to 10 years in OECD countries, a 10\% increase in output-oriented efficiency gains corresponds roughly to an additional year of schooling. Educational output is traditionally measured in the literature assessing the influence of education on growth as the average number of schooling years (Barro and Lee, 1993, 2001). Hanushek and Woessmann (2007) argue that this yardstick neglects cross-country differences in the quality of education. Such differences remain relatively contained among OECD countries and the scope of this methodological limit should not be overstated accordingly.

5. Structure of the population by educational attainment and age: table A1.2a and 3a; relative wages by level of education: table A9.1a; Average schooling years: table A1.5. 
22. Sensitivity analysis has been carried out in order to check that the results are relatively robust to the parameterisation of the model. Results are detailed in the Appendix.

23. The impact on growth of higher input-decreasing efficiency compared to the effect of a rise in output-increasing efficiency depends on the position of a country relative to the concave efficiency frontier as described in Sutherland et al. (2007). Accordingly, a country close to the frontier in the output-increasing direction but further away as regards input-decreasing efficiency could still gain more by increasing educational output at unchanged spending rather than cutting into spending in education.

\section{Results}

24. Results are presented in Annex 1 (Figure 1) for 12 OECD countries where all data were available. For each country, three graphs are shown which compare the impacts on the GDP level of output-increasing and input-decreasing efficiency in public spending in primary and lower-secondary education. In each graph, the impact on GDP of output-increasing efficiency gains is computed using different values for the impact on earnings and productivity of one additional year of education ${ }^{6}$-respectively $5 \%, 10 \%$ and $15 \%$. It is presented as an $80 \%$-confidence interval taking account of a possible spillover effect of output-increasing efficiency gains in primary and lower-secondary education to individuals leaving the educational system with higher educational attainment. The impact of inputdecreasing efficiency gains displayed in each graph is the same. The scope for possible efficiency gains, either output-increasing or input-decreasing, is assessed by Sutherland et al. (2007).

25. The long-run impact on the GDP level of output-increasing efficiency gains in primary and lower-secondary schools ranges from $2 \%$ to $6 \%$ on average in a first group of countries (United States, Germany, France, United Kingdom, Italy, Norway, New Zealand, Poland, Sweden). The mean possible output-increasing gain in school efficiency in this group of countries is close to $6.5 \%$. $^{7}$ Accordingly, these orders of magnitude are in line with the $3 \%$ to $6 \%$ range for one additional year of schooling found in the literature and discussed in Section 1 (see above). ${ }^{8}$

26. In a second group of countries (Canada, Spain, Finland), the long-run impact on the GDP level of output-increasing efficiency gains in schools is much lower. It ranges from $0.5 \%$ to $3.5 \%$. However, the mean possible output-increasing gain in school efficiency is very small in these three countries (less than 3\%). Thus, these results do not invalidate the above mentioned order of magnitude suggesting that one additional year of schooling raises the GDP level by $3 \%-6 \%$ in the long run.

27. In most countries, the impact on the GDP level of input-decreasing efficiency gains in primary and lower-secondary schools is much lower than the effect on activity of output-increasing efficiency improvements, and always lower than $1 \%$ of GDP. Sensitivity analysis in the Appendix suggests that taking account of one possible side-effect of lower spending in education -- i.e. lower distortionary taxes -- would not change much this order of magnitude.

28. From a qualitative standpoint, this result is rather intuitive. Input-decreasing efficiency gains entail shifting teachers from the public to the private sector where productivity gains are higher. Outputincreasing efficiency gains enhance the productivity of the whole future labour force. Since the size of the latter is far bigger than the number of teachers, a $1 \%$-increase in output-oriented efficiency has a bigger effect on GDP in the long run than a $1 \%$-increase in input-oriented efficiency.

\footnotetext{
6. I.e. the mincerian parameter $\mu$ in expression (3).

7. This corresponds to around 25 PISA scores or seven additional months of schooling with no extra-cost.

8. Unsurprisingly, results depend on the elasticity of earnings to the number of years of schooling $(\mu)$ and the intensity of spillover effects on the productivity of individuals with a tertiary educational attainment. The main results hold, however.
} 
29. From a quantitative point of view, the difference between the respective impacts on the GDP level of both ways of increasing efficiency in primary and lower-secondary education appears to be sizeable. In our sample, the average possible output-increasing gain is around $6 \%$ whereas the average possible input-decreasing gain is around $18 \%$ but even with such a difference, the macroeconomic consequences of output-oriented efficiency gains are more favourable than if public expenditure on education is lowered.

30. Two caveats apply to this general result:

- in Finland, the case for output-increasing efficiency is far more mixed, even in the long run, because this country is almost at the efficiency frontier in the output direction.

- the effect of input-decreasing efficiency gains materialises more quickly than the influence of output-increasing efficiency gains. Hence both ways of improving the performance of the primary and lower-secondary educational system are often equivalent as regards their respective effects on GDP in the first 5 years of the reform. ${ }^{9}$

9. This is for instance the case for the United States, France, Canada, Italy, Finland, Norway and Sweden, even assuming a high value for the rate of return of an additional year in $\operatorname{school}(\mu=15 \%)$. 


\section{APPENDIX. SENSITIVITY ANALYSIS}

31. In the case of output-increasing efficiency gains, much of the sensitivity of results to underlying assumptions of the model are directly embedded in the simulations which are presented with an $80 \%$-confidence interval. Higher output-increasing efficiency in the PSE system can bolster the productivity of individuals with higher educational attainment. In an upper-bound case, the productivity gains of individuals with higher education are equal to the productivity gains of workers with lowersecondary education. A lower-bound case corresponds to the absence of any effect of enhanced efficiency in PSE on the productivity of young workers with higher education.

32. To overcome the difficulties in assigning relative importance between these two polar scenarios, the approach adopted here is based on random weights, as applied in previous OECD studies constructing institutional indicators. This technique uses 1000 sets of randomly generated weights for each of the two scenarios envisaged to calculate 1000 values of $G_{t, j}^{\text {output }} .{ }^{10}$ The random weights are drawn from a uniform distribution between 0 and 1 and normalised so as to sum to 1 . This is equivalent to assuming complete uncertainty about the most appropriate value of the weights associated with the scenarios. Accordingly, the resulting distribution of $G_{t, j}^{\text {output }}$ reflects the possible range of values given no a priori information on the most appropriate value for each of the weights. $80 \%$ confidence intervals are calculated from these distributions.

33. Sensitivity analysis has also been carried out for values of the mincerian parameter $\mu$ ranging from $5 \%$ to $15 \%$. Figure 1 displays the results obtained for values of $5 \%, 10 \%$ and $15 \%$ in all countries. Not surprisingly, the higher the impact of education on wages, the higher the effect on growth of an increase in output-oriented efficiency in public schools. The choice of the value of $\mu$ has a significant influence on the average favourable impact on the GDP level. However, the basic result holds, according to which the gains are higher in most countries in the long run if efficiency increases are outputincreasing rather than input-decreasing.

34. In the case of input-decreasing efficiency gains, sensitivity analysis has been carried out for values of the annual structural gains of labour productivity in public primary and lower-secondary education $\left(\gamma_{p u b}\right)$ ranging from $-1 \%$ to $+0.5 \%$ per year. ${ }^{11}$

35. This range is in line with some recent studies relying on a methodology aiming to measure directly the productivity gains in education by comparing the dynamics of a quality-adjusted output with the dynamics of inputs in schools. Recent work at the UK Department for Education and Skills (2005) presents different measures of quality-adjusted educational output which imply that productivity gains may have been close to zero over the past years, or even negative. On French data, Beudaert's (2004) quality-adjusted volume index for public education services is broadly stable over the period 1992-2004, which suggests that productivity in PSE might have declined since the public PSE wage bill has

10. I.e., $\omega_{0,2005, j}^{\prime}=\omega_{0,2005, j}^{*}$ and $\omega_{0,2005, j}^{\prime}=\omega_{0,2005, j}$ in expression (2).

11. The baseline value for $\gamma_{p u b}$ is $0 \%$. 
increased. On Italian data, Collesi (2000) shows that productivity gains in education could be close to zero in the 1990s. Overall, results remain very sensitive to the quality-adjustment method. A cautious approach has been adopted here and simulations were carried out for a range of values of productivity gains in public PSE.

36. Figure 2 shows that the results obtained are reasonably robust to the value chosen for the structural annual change of productivity in primary and lower-secondary education.

37. Baseline simulations in the case of input-oriented efficiency gains do not take account of the favourable impact on growth deriving from lower taxes and distortive effects on factor markets. Such effects are complex and inter-related and can not be assessed precisely in this simplified framework. However, sensitivity analysis can ensure that the effect on GDP of lower taxes allowed by lower public expenditures in primary and lower-secondary education remains limited and does not modify the main conclusions of the paper.

38. In this context, expression (1) in the main text is modified by adding a second term at the righthand side which measures the favourable impact on growth deriving from lower distortive taxes financing primary and lower-secondary public schools. This effect can be defined as:

$$
\mathrm{T}_{t, j}^{\text {input }}=-\frac{E X P_{2005, j}^{P S E}}{\delta_{j}} \alpha_{j} \varepsilon \delta_{j}=-E_{2005, j}^{P S E} \alpha_{j} \varepsilon>0
$$

where:

- $\mathrm{T}_{t, j}^{\text {input }}$ stands for the favourable impact on growth deriving from lower distortive taxes financing lower spending in primary and lower-secondary public schools in country $j$ at year $t$,

- $\quad \delta_{j}$ stands for the share of labour in the value added of the business sector in country $j$

- $\quad E X P_{2005, j}^{P S E}$ refers to the public expenditure in primary and lower-secondary education (as a \% of GDP) in country $j$,

- $\quad \alpha_{j}$ stands for input-oriented efficiency gains (in \%) in country $j$

- $\varepsilon<0$ is the elasticity of the labour force to a proportional tax.

39. With this specification, $E X P_{2005, j}^{P S E} / \delta_{j}$ stands for an implicit proportional tax on labour financing public primary and lower-secondary education; and $-\left(E X P_{2005, j}^{P S E} / \delta_{j}\right) \alpha_{j} \varepsilon$ to the favourable impact on business employment deriving from lower distortive taxes financing primary and lowersecondary public schools.

40. The value of the elasticity of the labour force to a proportional tax $\varepsilon<0$ is set at -0.3 . Standard orders of magnitude for the elasticity of the labour supply suggest a value comprised on average between -0.1 and -0.3 (cf. Nickell and Layard, 1999; Cahuc and Zylberberg, 2001; Nickell, 2004; Alesina et al. 2005). ${ }^{12}$ The upper limit of the range of possible values for this parameter has been selected to make up for a possible underestimation due to neglecting distortive effects of the tax system on the capital

12. Prescott's (2004) estimate of -0.8 has been strongly criticized (Alesina et al., 2005) and considered as an outlier in the literature (Nickell, 2004). 
markets in this framework. The assumption of proportionality of the tax seems accurate for long-run simulations. The results are robust to the value of $\varepsilon<0$ since the amount of tax cuts in percentage points is limited, as teachers transferred to the private sector in the simulations account for a limited fraction of business employment (a few percentage points on average).

41. Figure 3 shows the results obtained. Taking account of the favourable influence on growth of lowering distortive taxes financing public expenditures in primary and lower secondary education increases the impact on the level of GDP of higher input-oriented efficiency. However, the effect remains relatively limited, so that the main conclusions of this exercise remain unchanged, whether distortive taxes are taken into account or not. 


\section{ANNEX 1. TABLE AND FIGURES}

\section{Table}

A1.DEA estimates of technical efficiency in primary and lower-secondary education

\section{Figures}

1. Impact on the GDP level of higher efficiency in public spending in primary and lower-secondary education (in \%)

2. Sensitivity analysis on the value of the annual structural gains of labour productivity in public primary and lower-secondary education

3. Sensitivity analysis: impact on growth of lessening the level of distortive taxes on labour financing public schools 
ECO/WKP(2007)7

Table A1. DEA estimates of maximum possible efficiency gains in primary and lower-secondary education

\begin{tabular}{|c|c|c|}
\hline \multirow[t]{2}{*}{ (in \%) } & Input efficiency & Output efficiency \\
\hline & NIRS & NIRS \\
\hline Australia & 15.9 & 4.8 \\
\hline Austria & 15.9 & 6.0 \\
\hline Belgium Flemish c. & 15.0 & 2.0 \\
\hline Belgium French c. & 18.8 & 9.8 \\
\hline Canada & 23.4 & 3.3 \\
\hline Czech Republic & 16.4 & 6.0 \\
\hline Denmark & 21.0 & 4.9 \\
\hline Finland & 10.6 & 1.6 \\
\hline France & 10.0 & 5.4 \\
\hline Germany & 18.5 & 9.1 \\
\hline Greece & 20.6 & 7.0 \\
\hline Hungary & 14.1 & 4.7 \\
\hline Iceland & 30.5 & 4.8 \\
\hline Ireland & 9.5 & 2.2 \\
\hline Italy & 17.8 & 6.9 \\
\hline Japan & 7.6 & 3.9 \\
\hline Korea & 10.8 & 3.9 \\
\hline Luxembourg & 21.6 & 6.9 \\
\hline Mexico & 10.1 & 3.9 \\
\hline Netherlands & 12.8 & 5.1 \\
\hline New Zealand & 15.8 & 4.9 \\
\hline Norway & 29.2 & 7.4 \\
\hline Poland & 11.3 & 3.8 \\
\hline Portugal & 4.6 & 2.2 \\
\hline Slovak Republic & 15.9 & 5.3 \\
\hline Spain & 11.3 & 3.4 \\
\hline Sweden & 18.8 & 6.0 \\
\hline Switzerland & 9.6 & 5.2 \\
\hline Turkey & 7.5 & 3.5 \\
\hline United Kingdom & 18.1 & 6.1 \\
\hline United States & 25.5 & 8.2 \\
\hline Average & 15.8 & 5.1 \\
\hline
\end{tabular}

Note: NIRS = non-increasing returns to scale.

Bootstrap estimates with 2 inputs (teachers per 100 students and socio-economic background)

and 2 outputs (average PISA score and homogeneity of PISA score).

Source: Sutherland, Joumard, Price and Nicq (2007). 
Figure 1. Impact on the GDP level of higher efficiency in public spending in primary and lower-secondary education (in \%)

\section{UNITED STATES}

Rate of return of one additional year in primary and secondary education: $\mu=5 \%$

USA

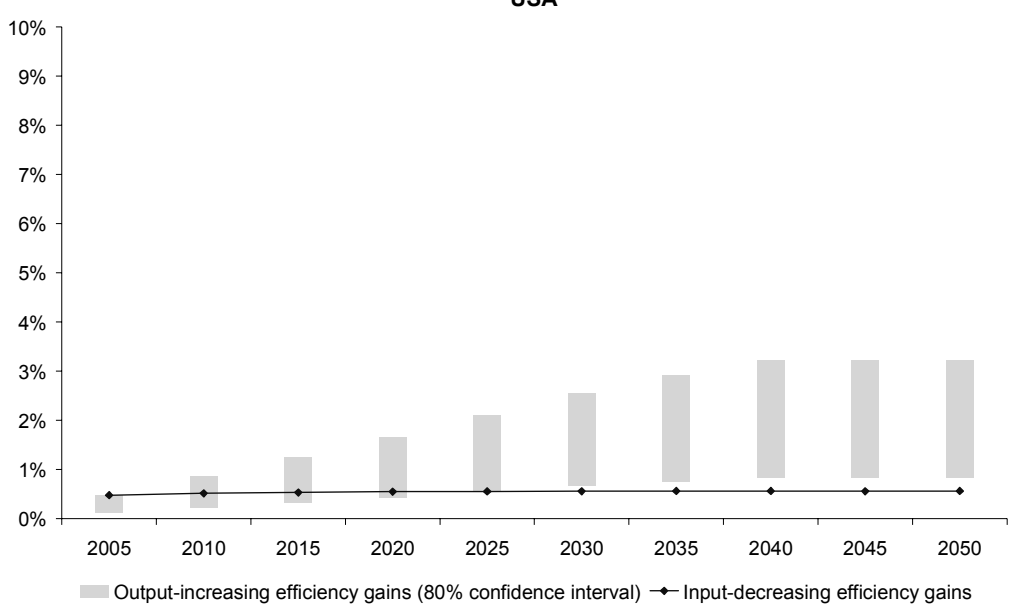

Rate of return of one additional year in primary and secondary education: $\mu=10 \%$

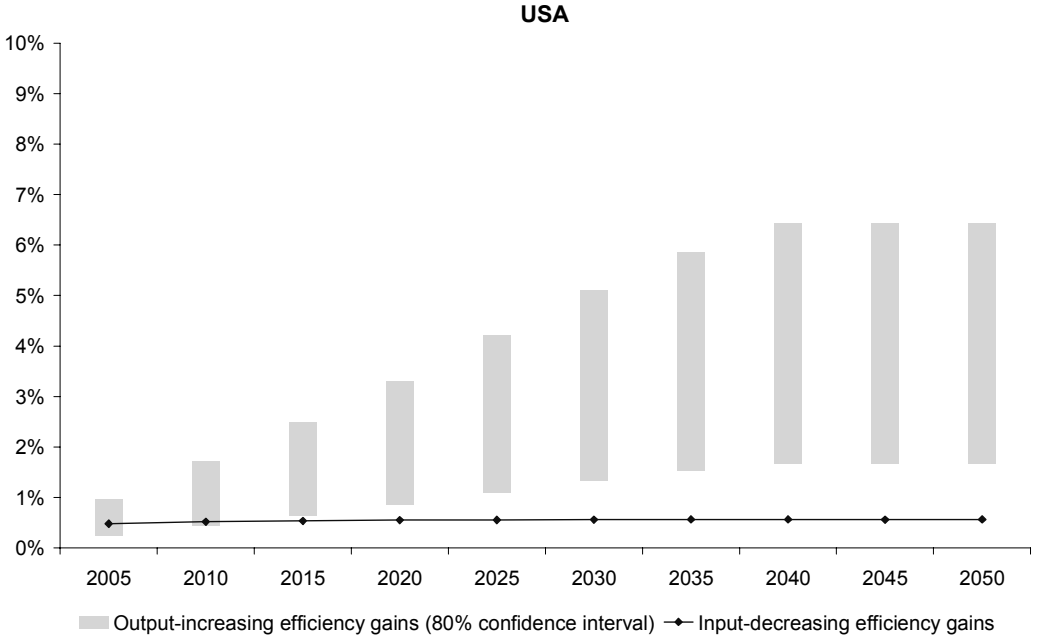

Rate of return of one additional year in primary and secondary education: $\mu=15 \%$

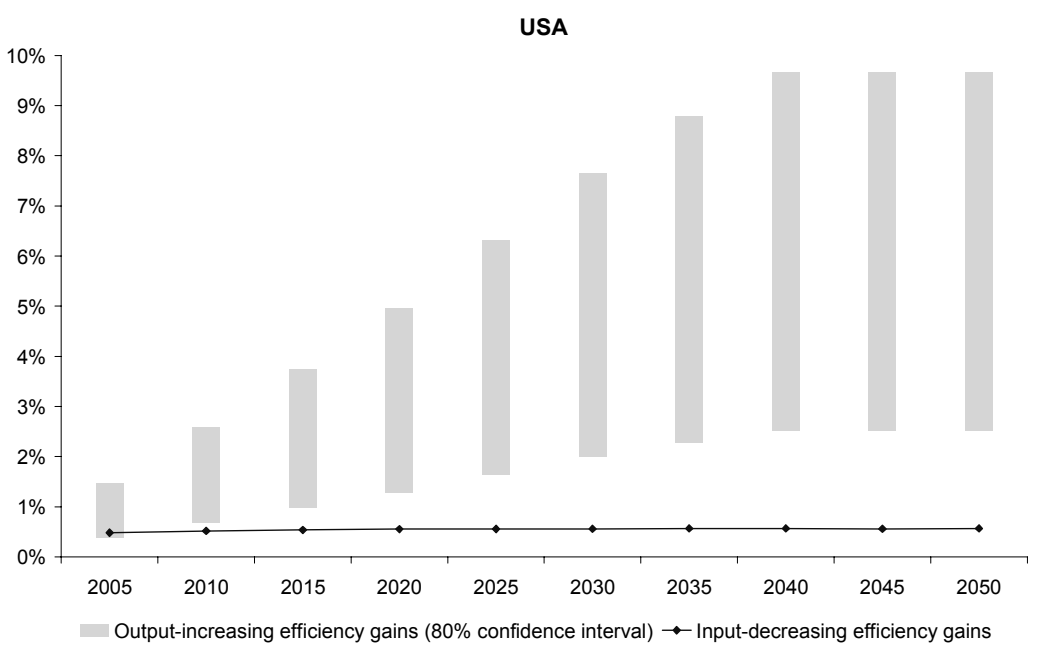


Figure 1 (cont'd). Impact on the GDP level of higher efficiency in public spending in primary and lowersecondary education (in \%)

\section{GERMANY}

Rate of return of one additional year in primary and secondary education: $\mu=5 \%$

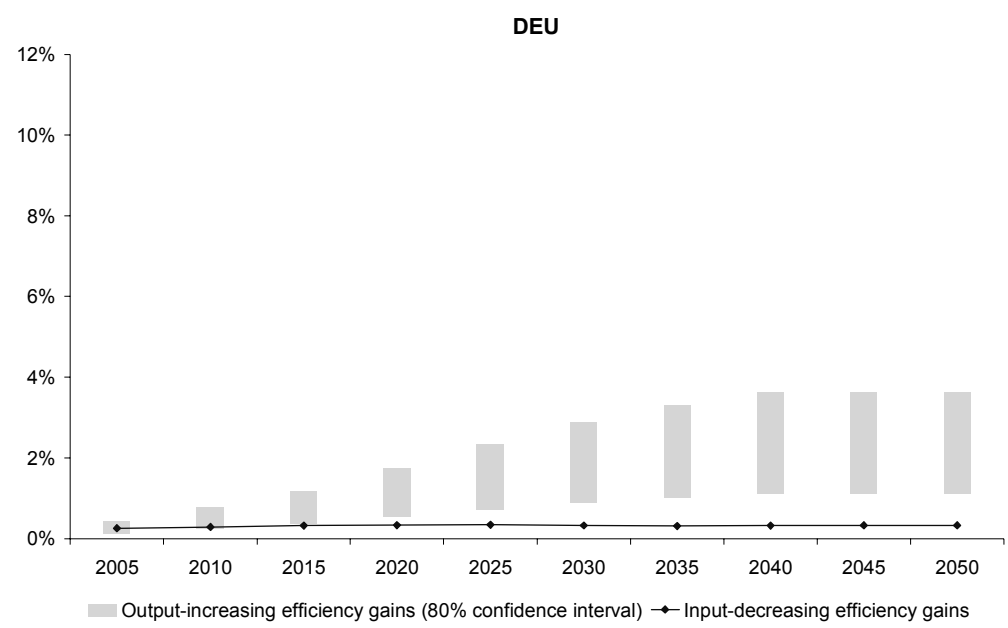

Rate of return of one additional year in primary and secondary education: $\mu=10 \%$

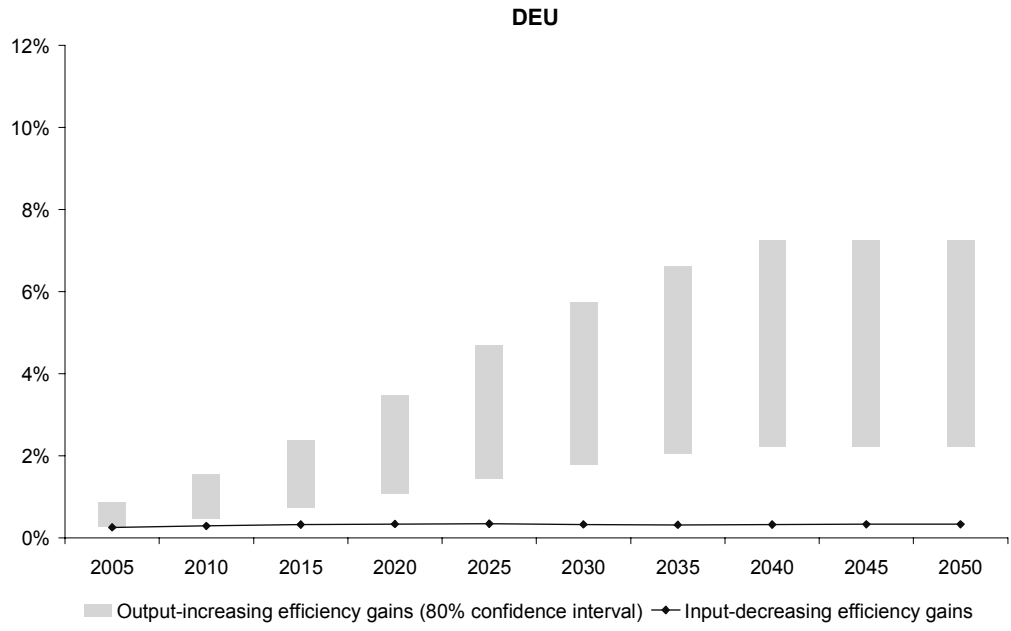

Rate of return of one additional year in primary and secondary education: $\mu=15 \%$

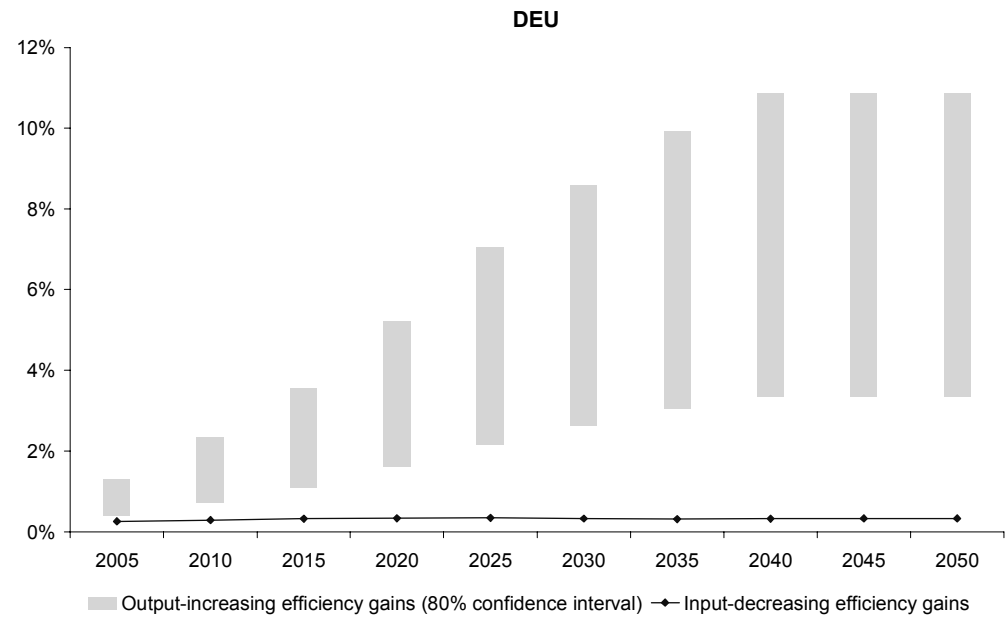


Figure 1 (cont'd). Impact on the GDP level of higher efficiency in public spending in primary and lowersecondary education (in \%)

FRANCE

Rate of return of one additional year in primary and secondary education: $\mu=5 \%$

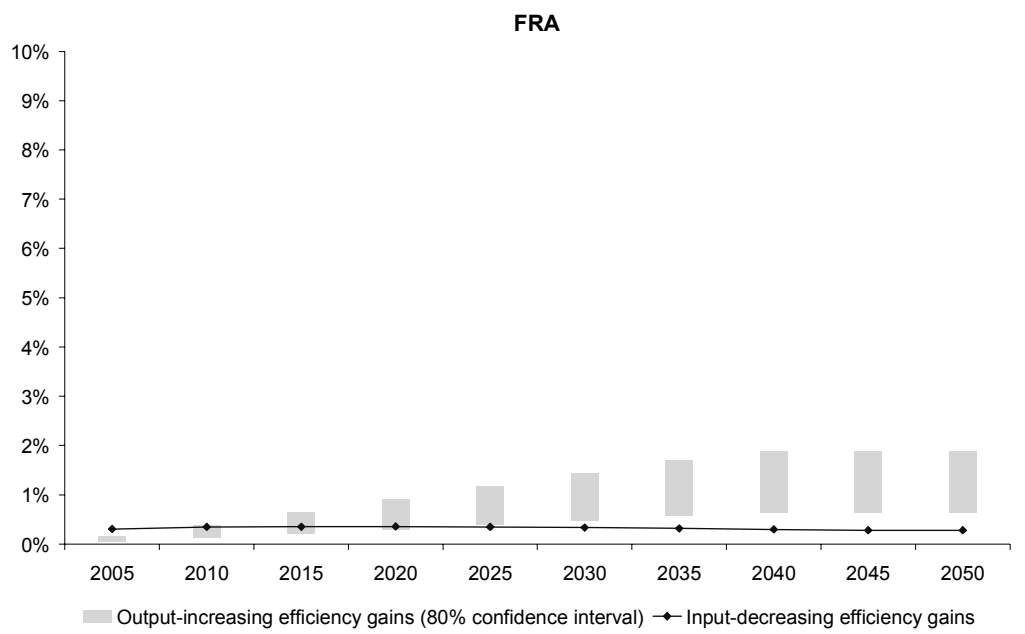

Rate of return of one additional year in primary and secondary education: $\mu=10 \%$

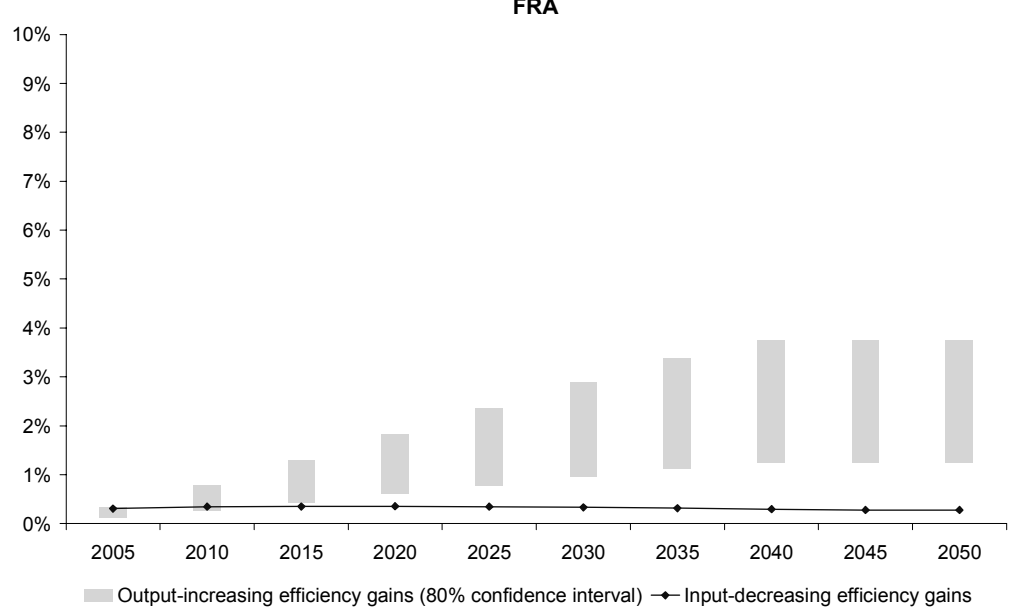

Rate of return of one additional year in primary and secondary education: $\mu=15 \%$

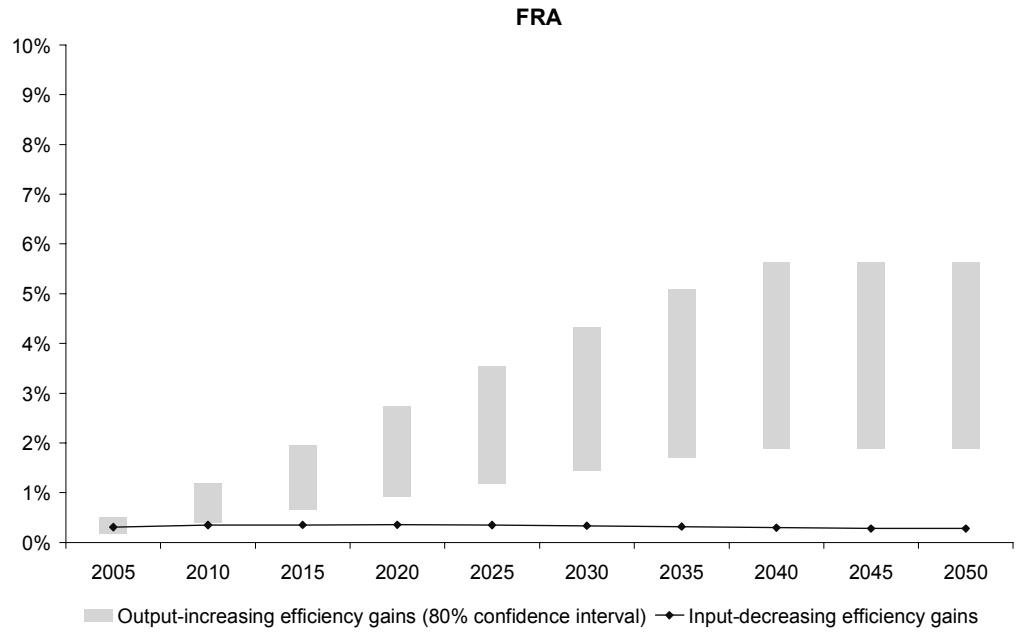


Figure 1 (cont'd). Impact on the GDP level of higher efficiency in public spending in primary and lowersecondary education (in \%)

\section{UNITED KINGDOM}

Rate of return of one additional year in primary and secondary education: $\mu=5 \%$

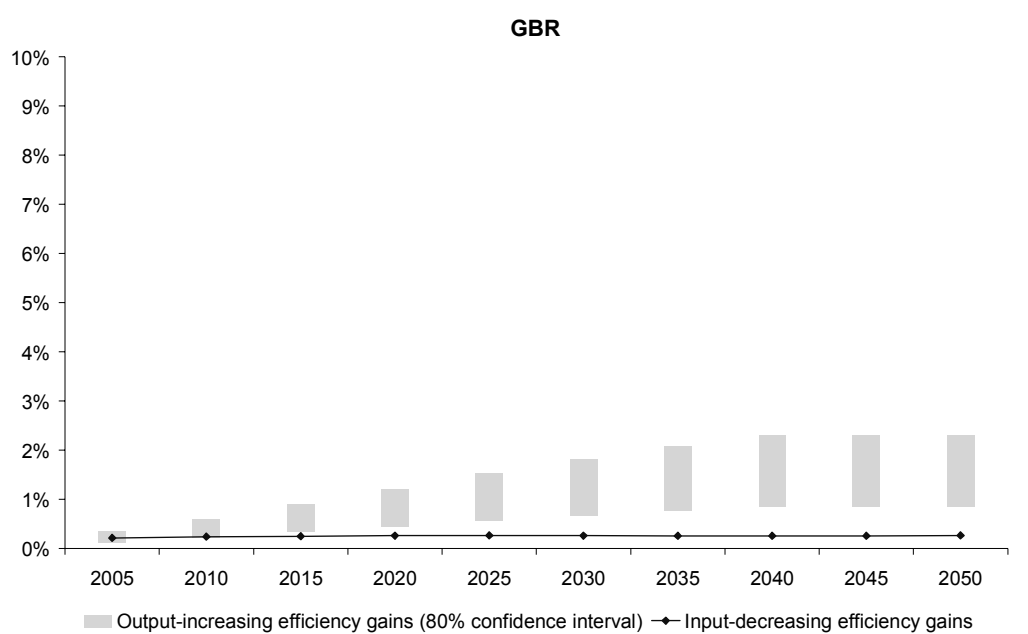

Rate of return of one additional year in primary and secondary education: $\mu=10 \%$

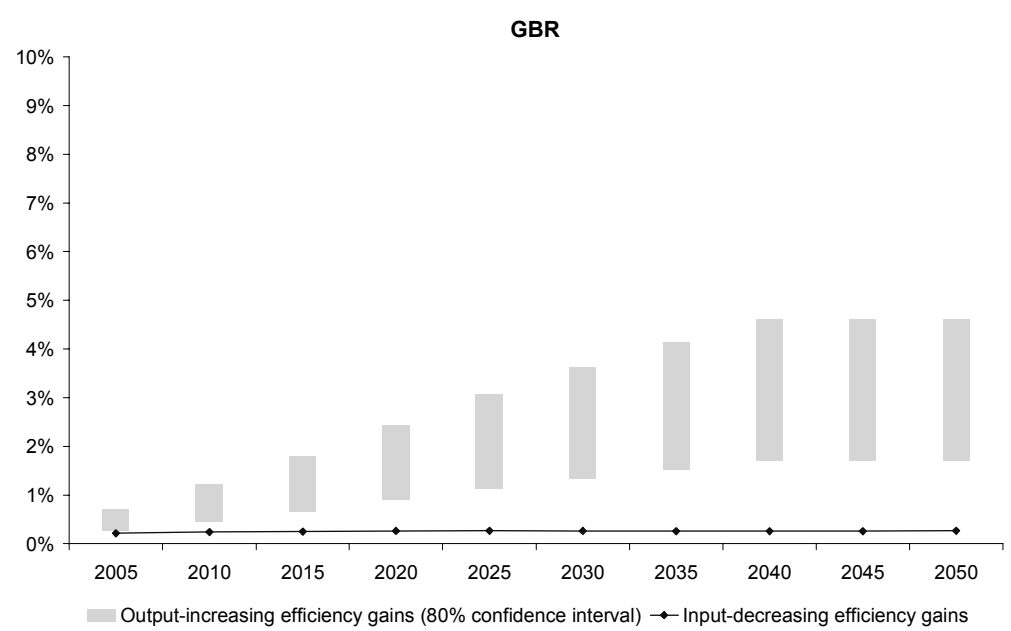

Rate of return of one additional year in primary and secondary education: $\mu=15 \%$

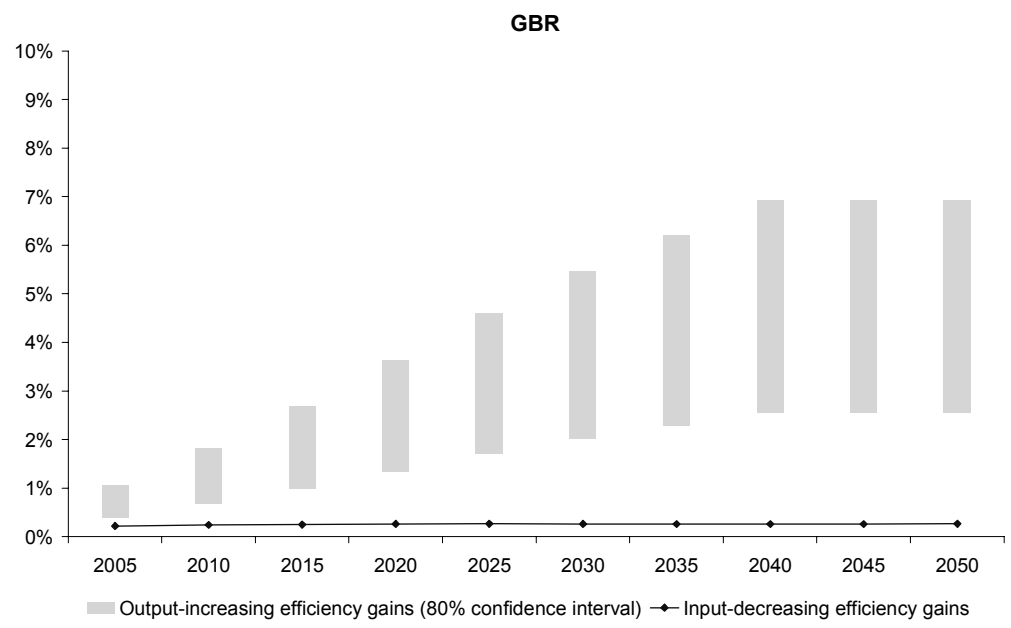


Figure 1 (cont'd). Impact on the GDP level of higher efficiency in public spending in primary and lowersecondary education (in \%)

\section{CANADA}

Rate of return of one additional year in primary and secondary education: $\mu=5 \%$

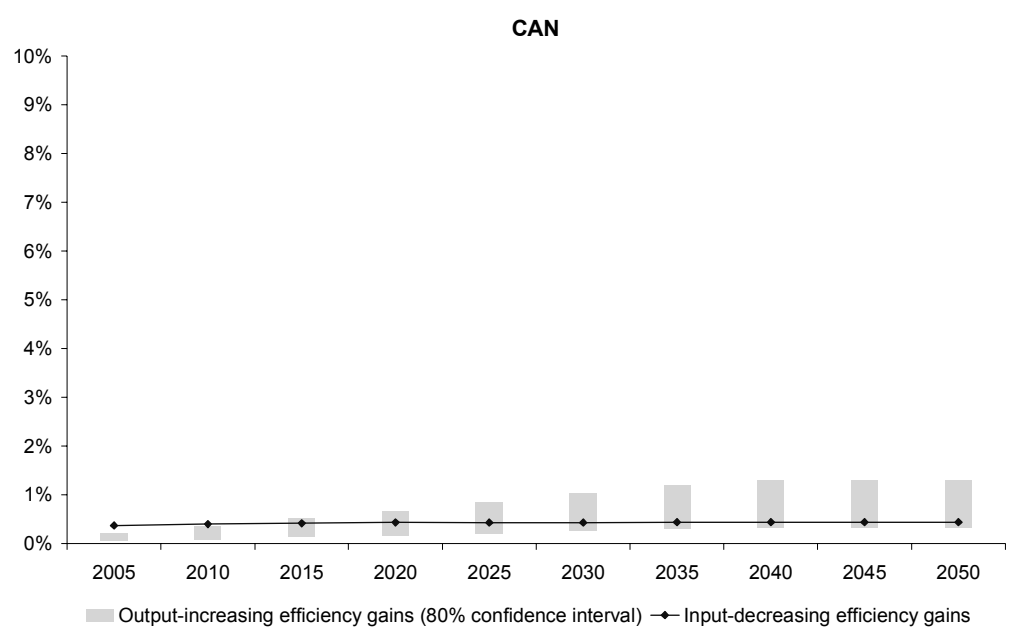

Rate of return of one additional year in primary and secondary education: $\mu=10 \%$

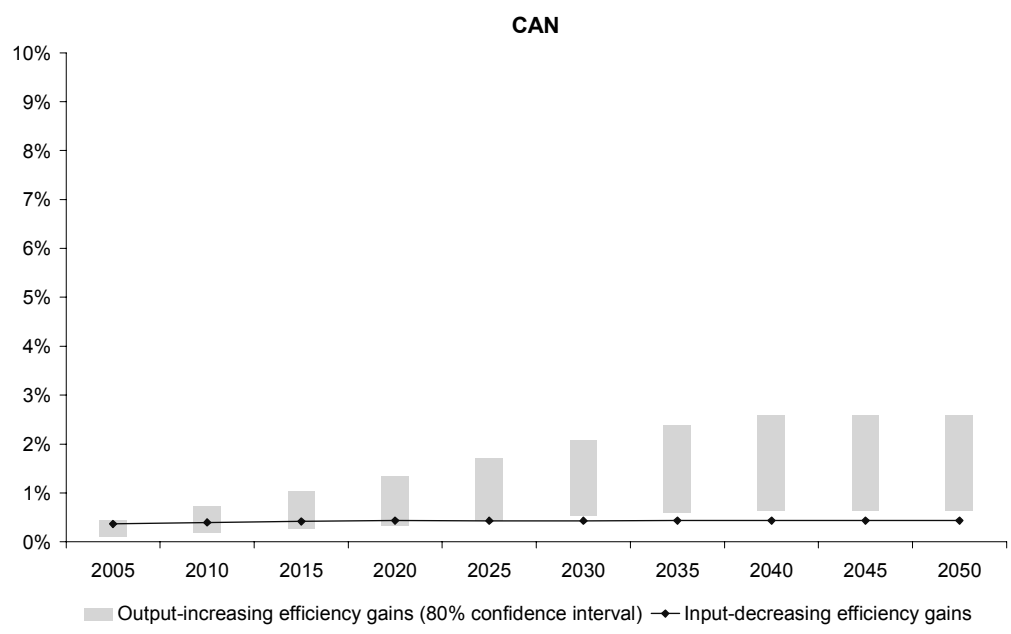

Rate of return of one additional year in primary and secondary education: $\mu=15 \%$

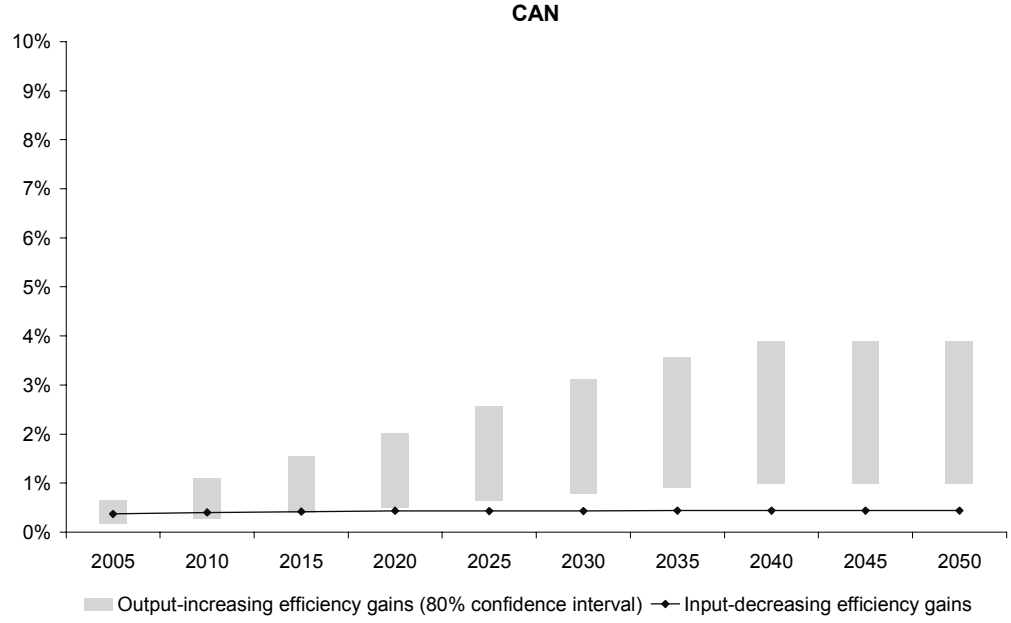


Figure 1 (cont'd). Impact on the GDP level of higher efficiency in public spending in primary and lowersecondary education (in \%)

\section{ITALY}

Rate of return of one additional year in primary and secondary education: $\mu=5 \%$

ITA

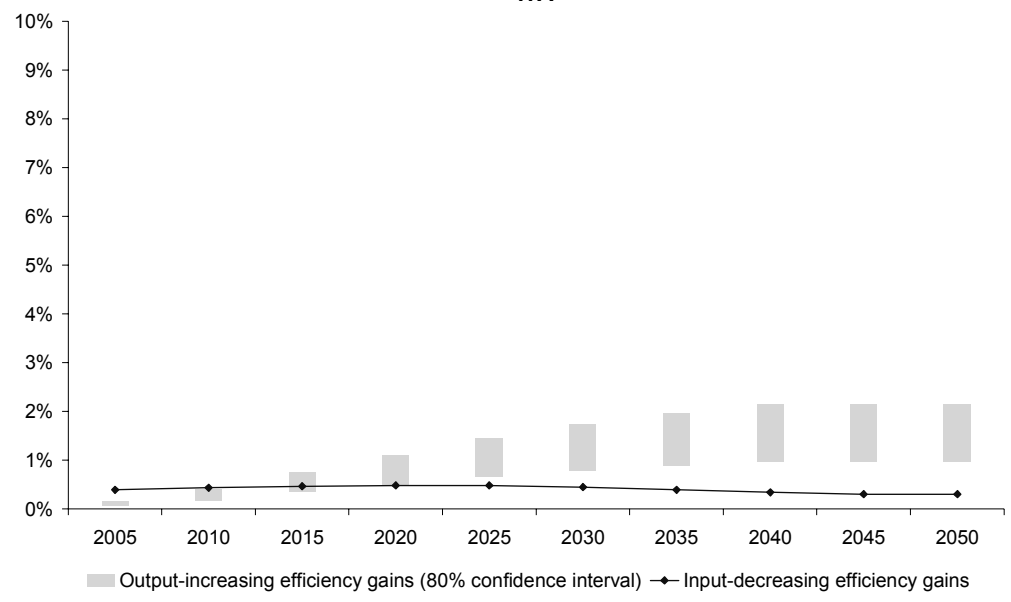

Rate of return of one additional year in primary and secondary education: $\mu=10 \%$

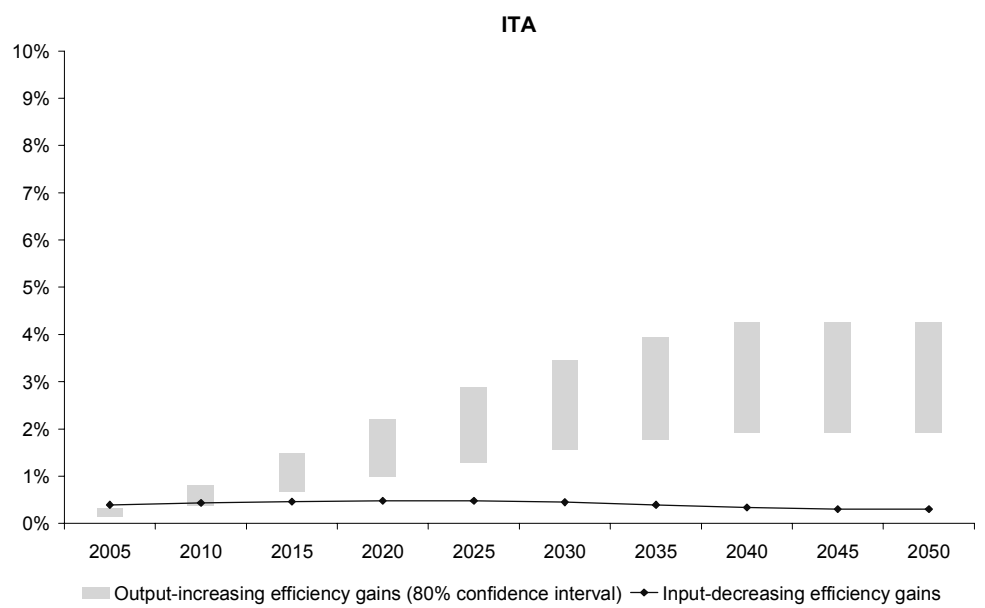

Rate of return of one additional year in primary and secondary education: $\mu=15 \%$

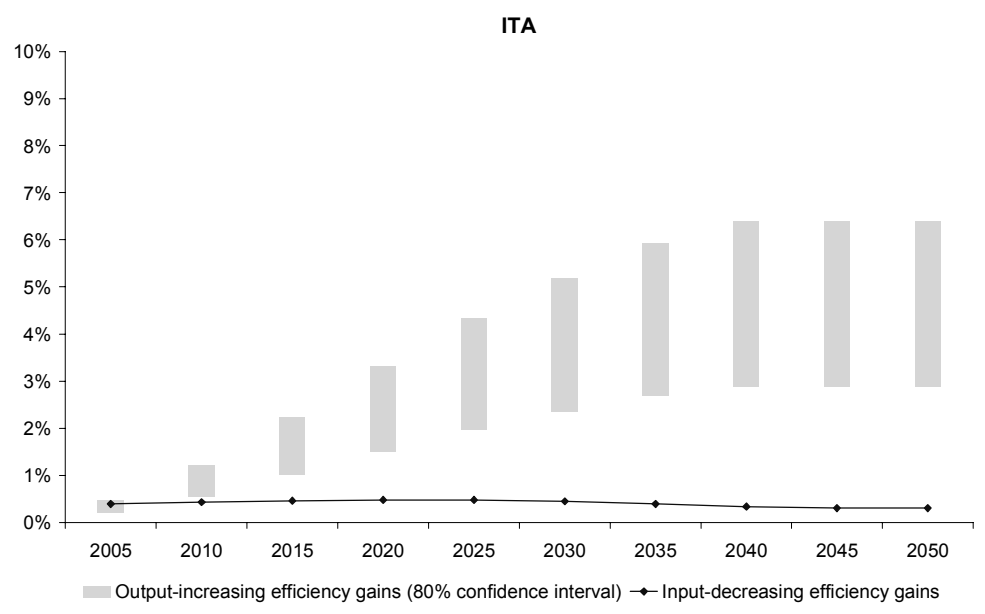


Figure 1 (cont'd). Impact on the GDP level of higher efficiency in public spending in primary and lowersecondary education (in \%)

\section{SPAIN}

Rate of return of one additional year in primary and secondary education: $\mu=5 \%$

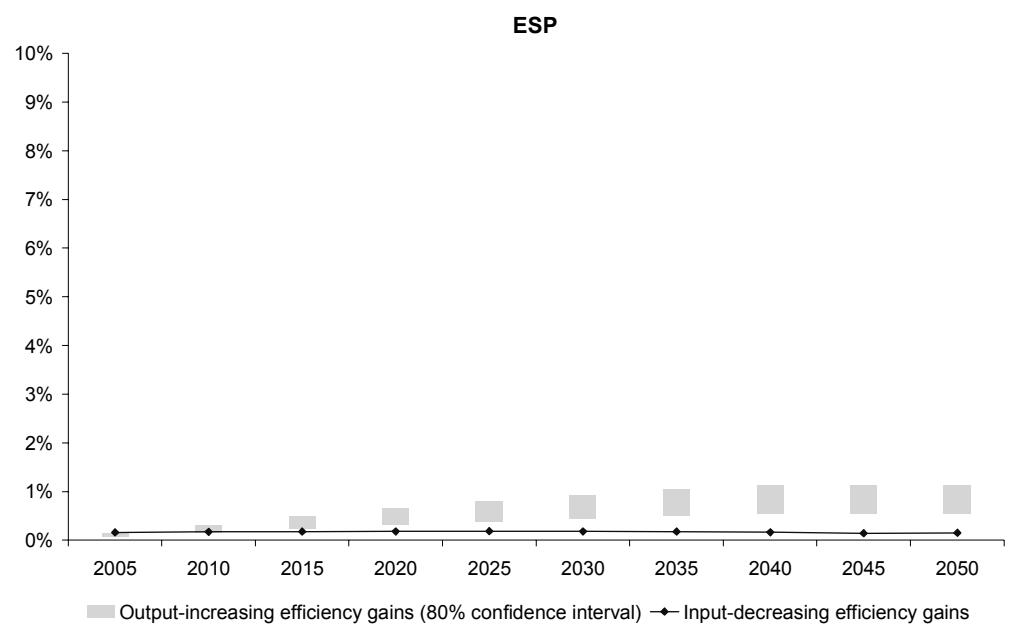

Rate of return of one additional year in primary and secondary education: $\mu=10 \%$

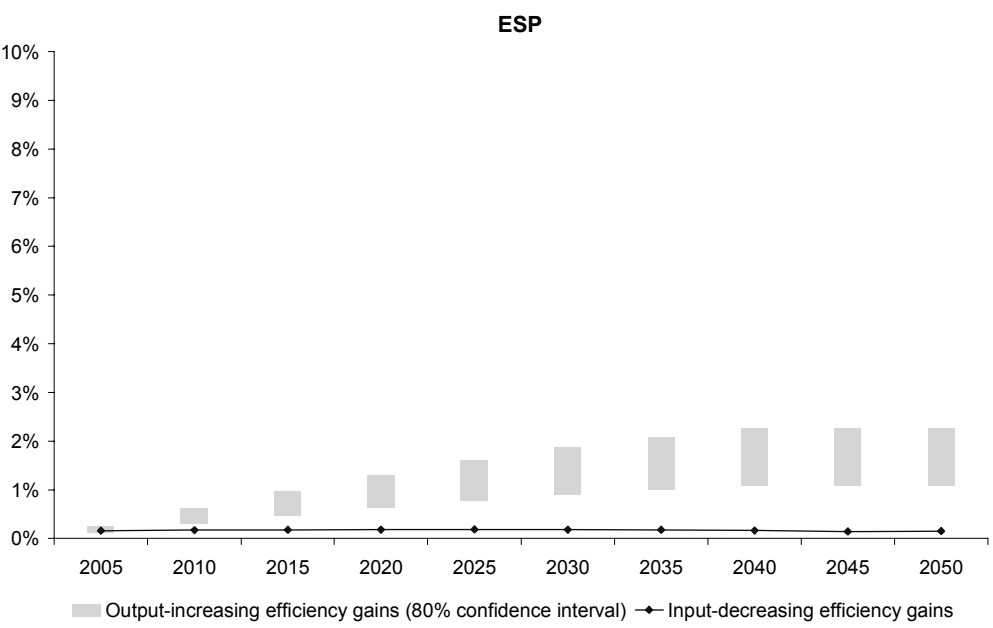

Rate of return of one additional year in primary and secondary education: $\mu=15 \%$

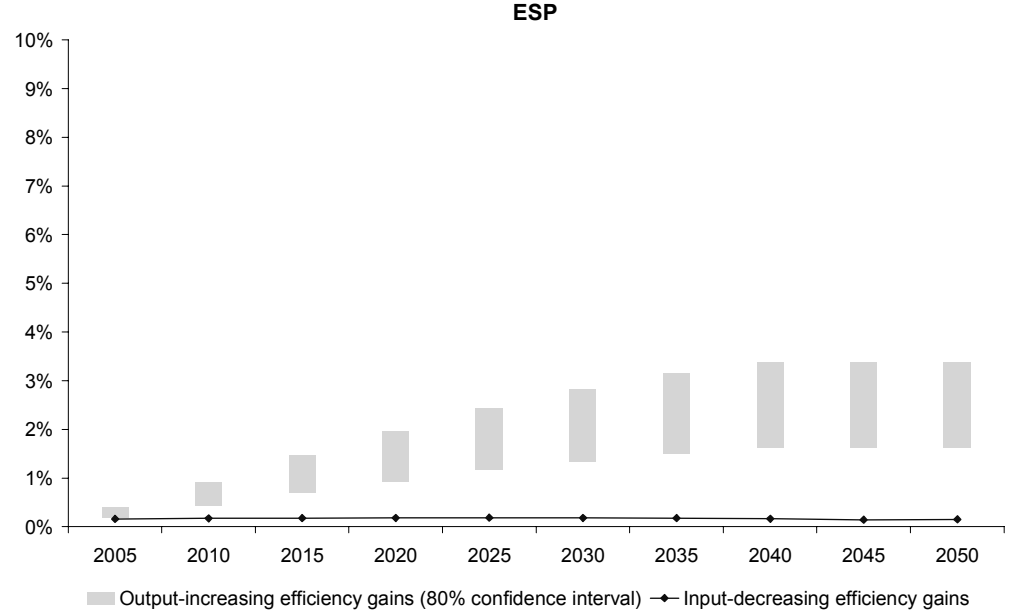


Figure 1 (cont'd). Impact on the GDP level of higher efficiency in public spending in primary and lowersecondary education (in \%)

\section{FINLAND}

Rate of return of one additional year in primary and secondary education: $\mu=5 \%$

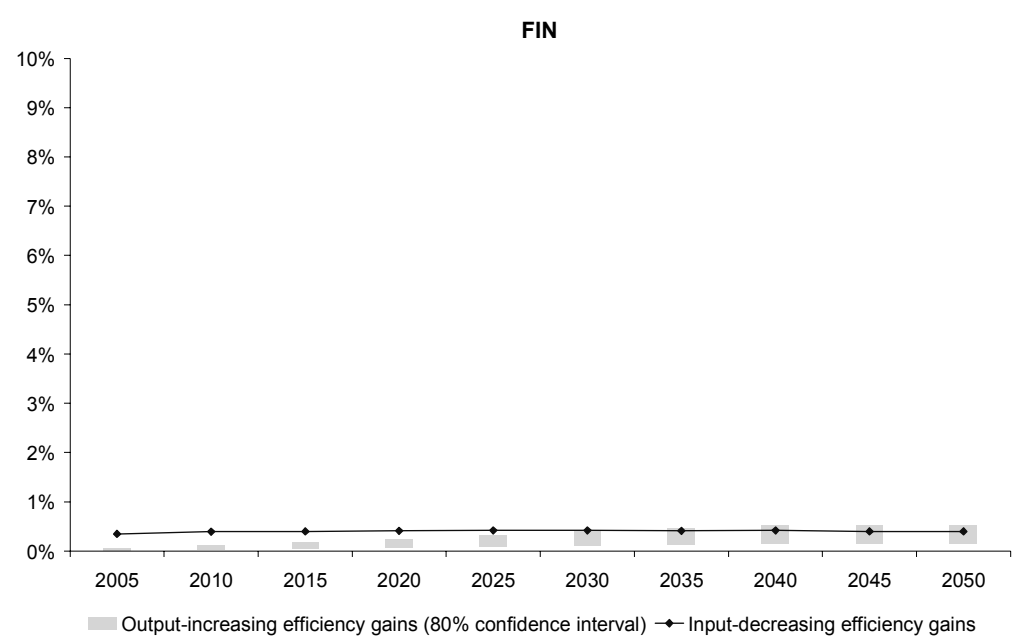

Rate of return of one additional year in primary and secondary education: $\mu=10 \%$

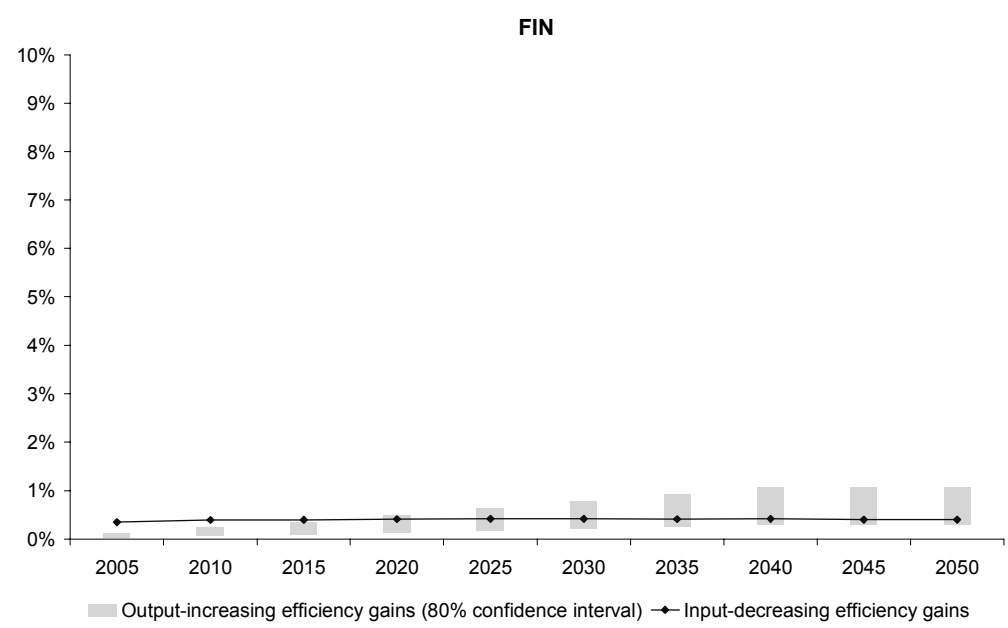

Rate of return of one additional year in primary and secondary education: $\mu=15 \%$

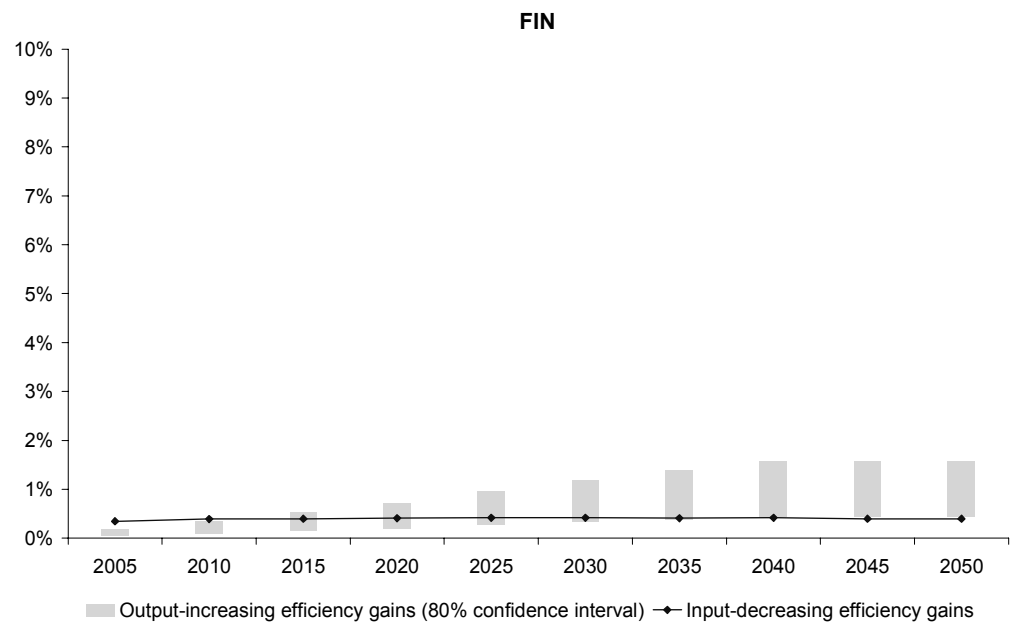


Figure 1 (cont'd). Impact on the GDP level of higher efficiency in public spending in primary and lowersecondary education (in \%)

\section{NORWAY}

Rate of return of one additional year in primary and secondary education: $\mu=5 \%$

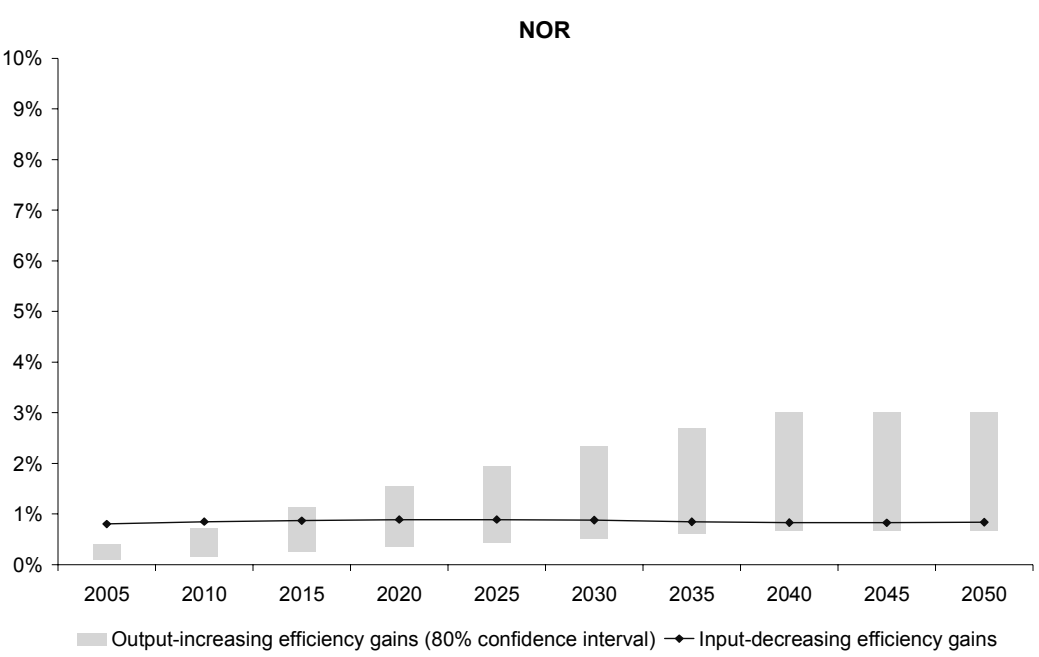

Rate of return of one additional year in primary and secondary education: $\mu=10 \%$

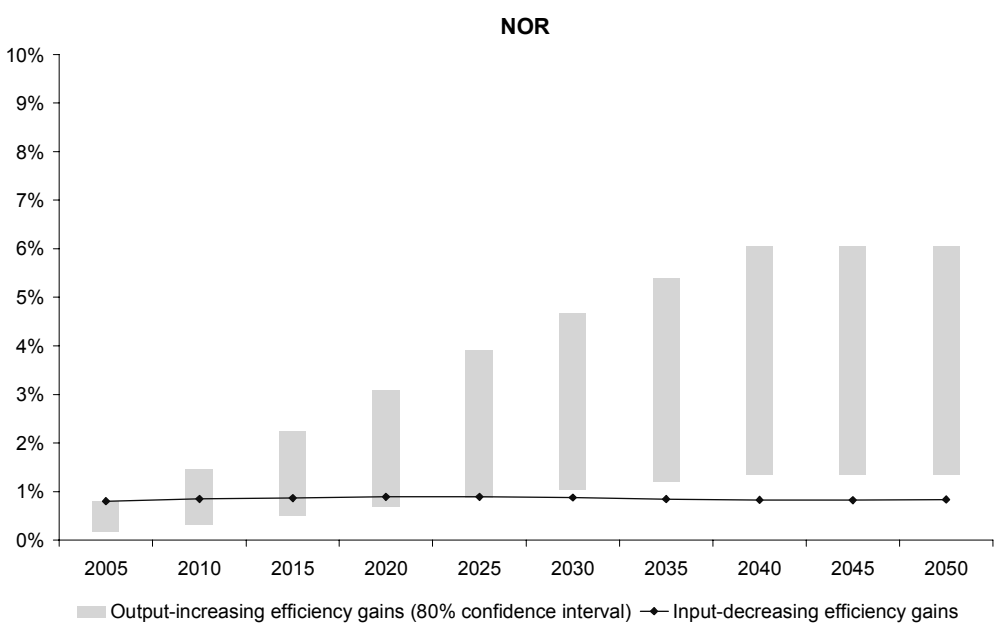

Rate of return of one additional year in primary and secondary education: $\mu=15 \%$

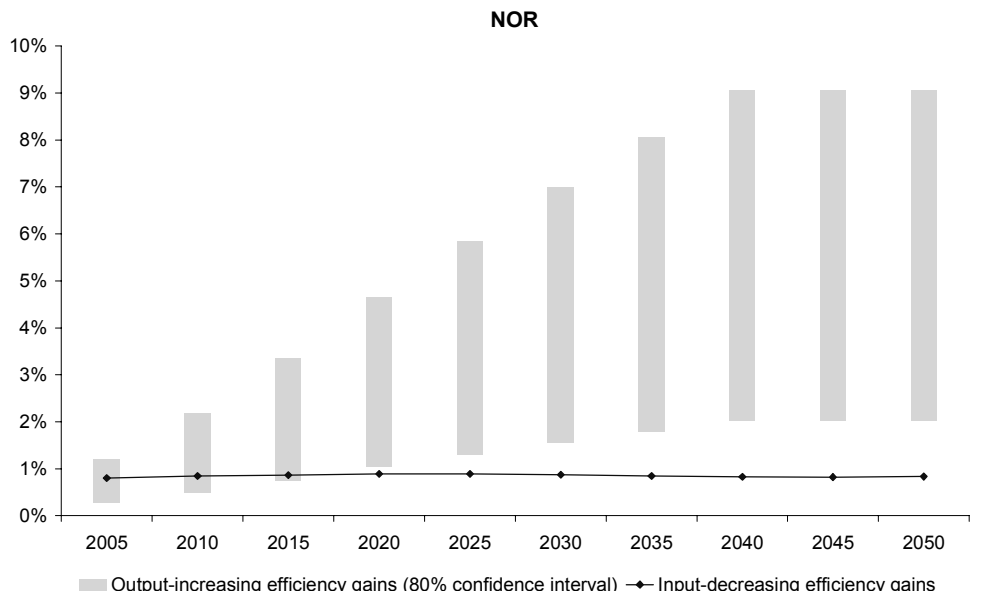


Figure 1 (cont'd). Impact on the GDP level of higher efficiency in public spending in primary and lowersecondary education (in \%)

NEW ZEALAND

Rate of return of one additional year in primary and secondary education: $\mu=5 \%$

NZL

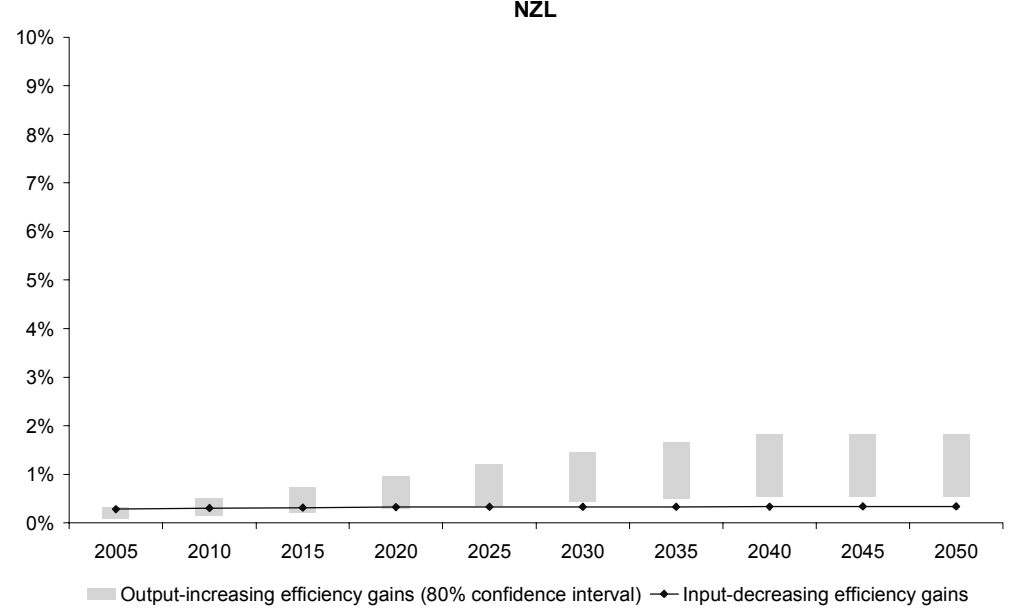

Rate of return of one additional year in primary and secondary education: $\mu=10 \%$

NZL

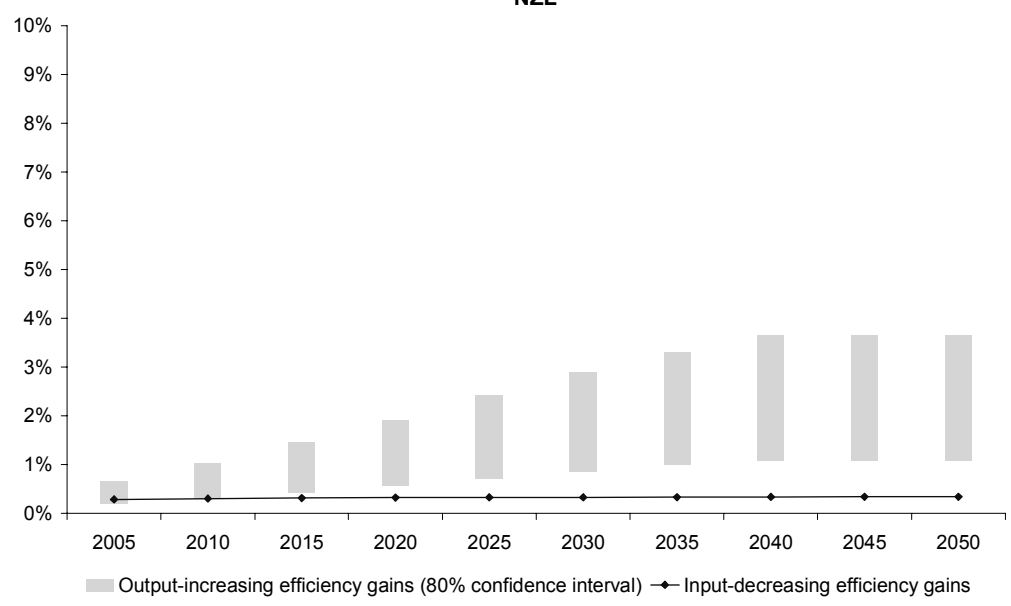

Rate of return of one additional year in primary and secondary education: $\mu=15 \%$

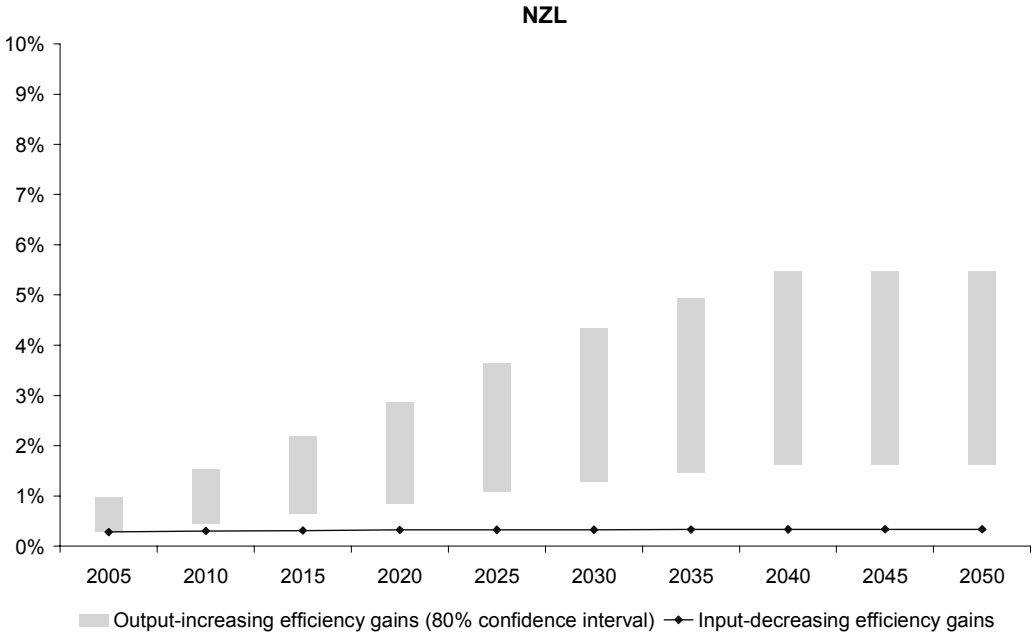


Figure 1 (cont'd). Impact on the GDP level of higher efficiency in public spending in primary and lowersecondary education (in \%)

POLAND

Rate of return of one additional year in primary and secondary education: $\mu=5 \%$

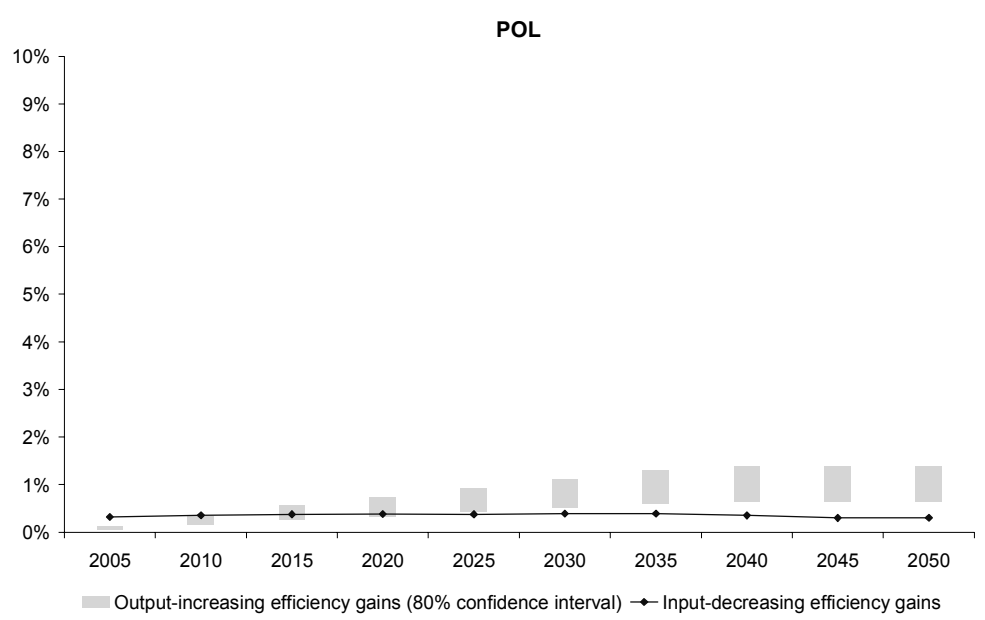

Rate of return of one additional year in primary and secondary education: $\mu=10 \%$

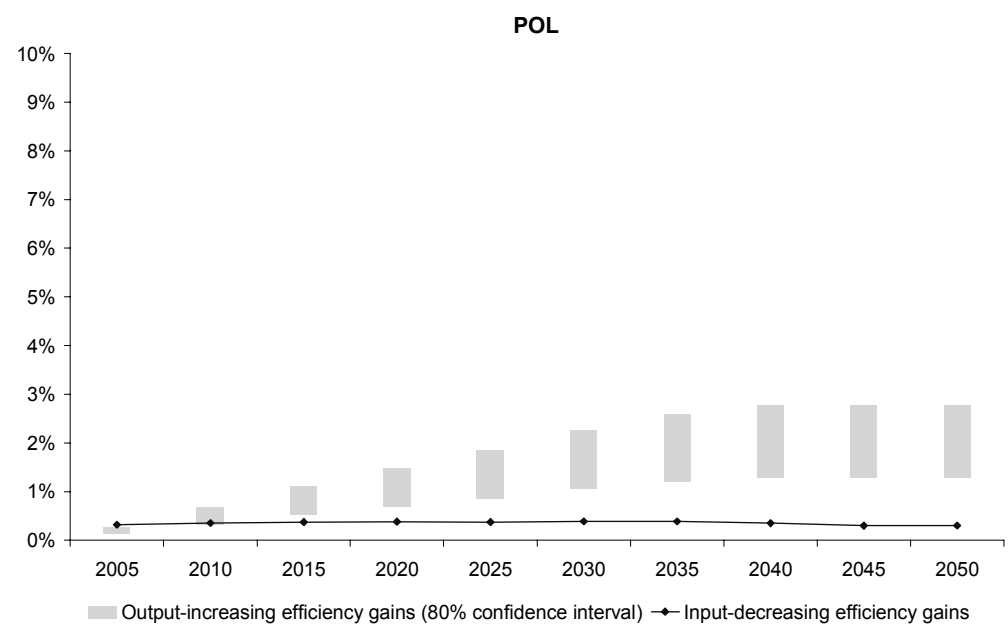

Rate of return of one additional year in primary and secondary education: $\mu=15 \%$

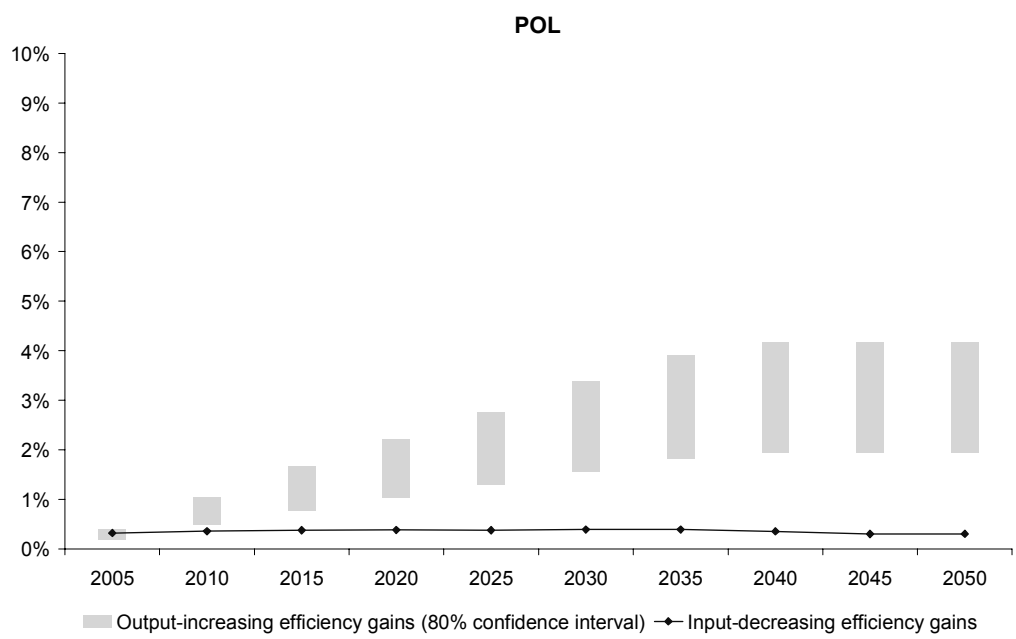


Figure 1 (cont'd). Impact on the GDP level of higher efficiency in public spending in primary and lowersecondary education (in \%)

\section{SWEDEN}

Rate of return of one additional year in primary and secondary education: $\mu=5 \%$

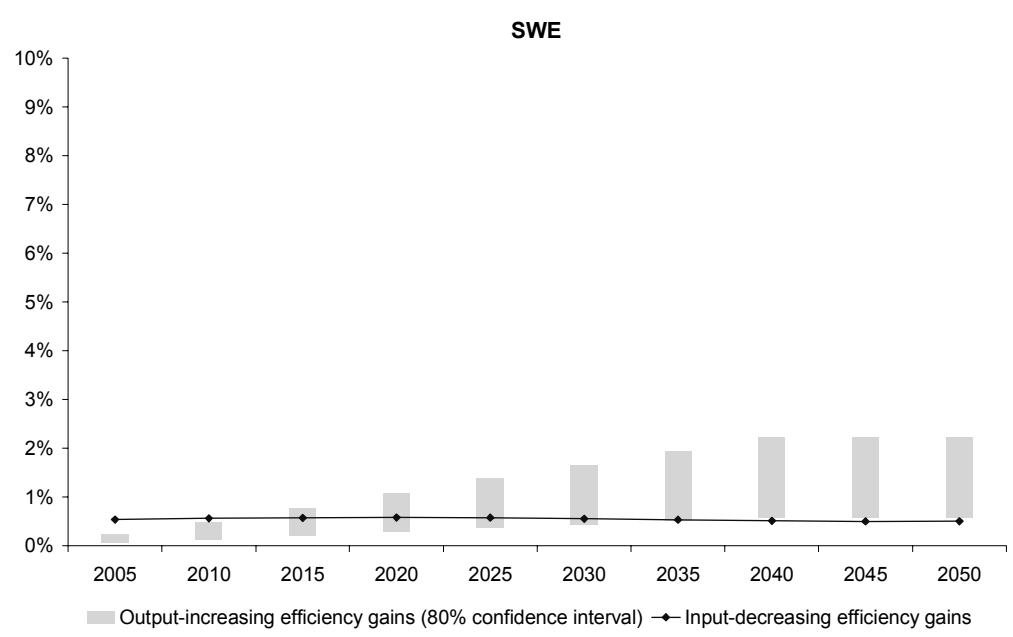

Rate of return of one additional year in primary and secondary education: $\mu=10 \%$

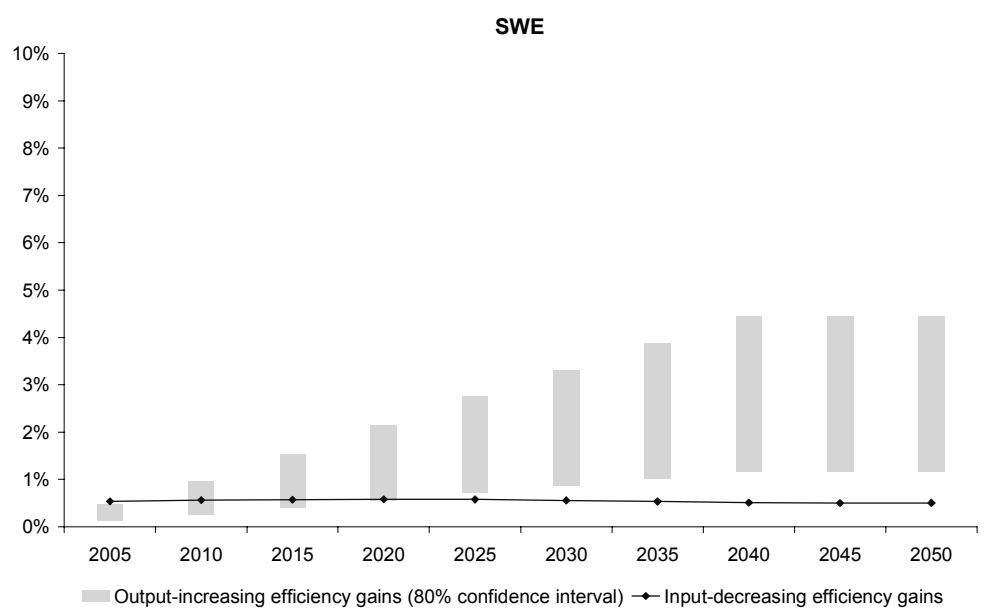

Rate of return of one additional year in primary and secondary education: $\mu=15 \%$

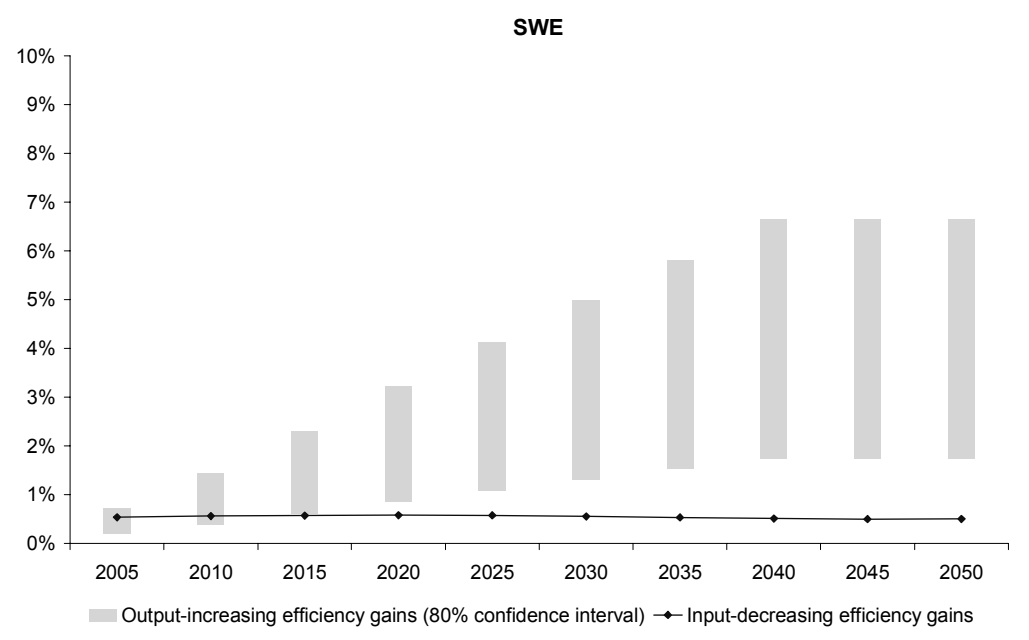


Figure 2. Sensitivity analysis on the value of the annual structural gains of labour productivity in public primary and lower-secondary education

\section{FRANCE}

FRA

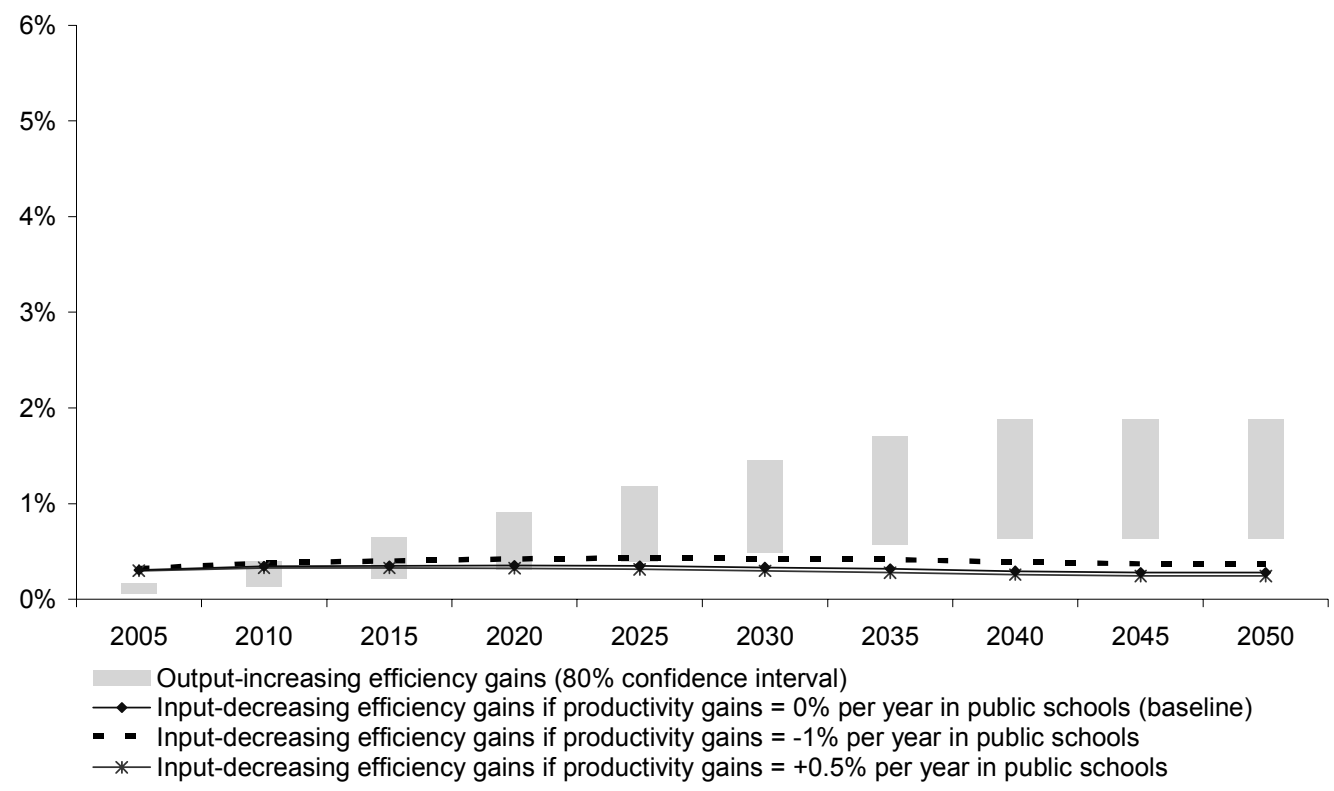

Figure 3. Sensitivity analysis: impact on growth of lessening the level of distortive taxes on labour financing public schools

\section{FRANCE}

FRA

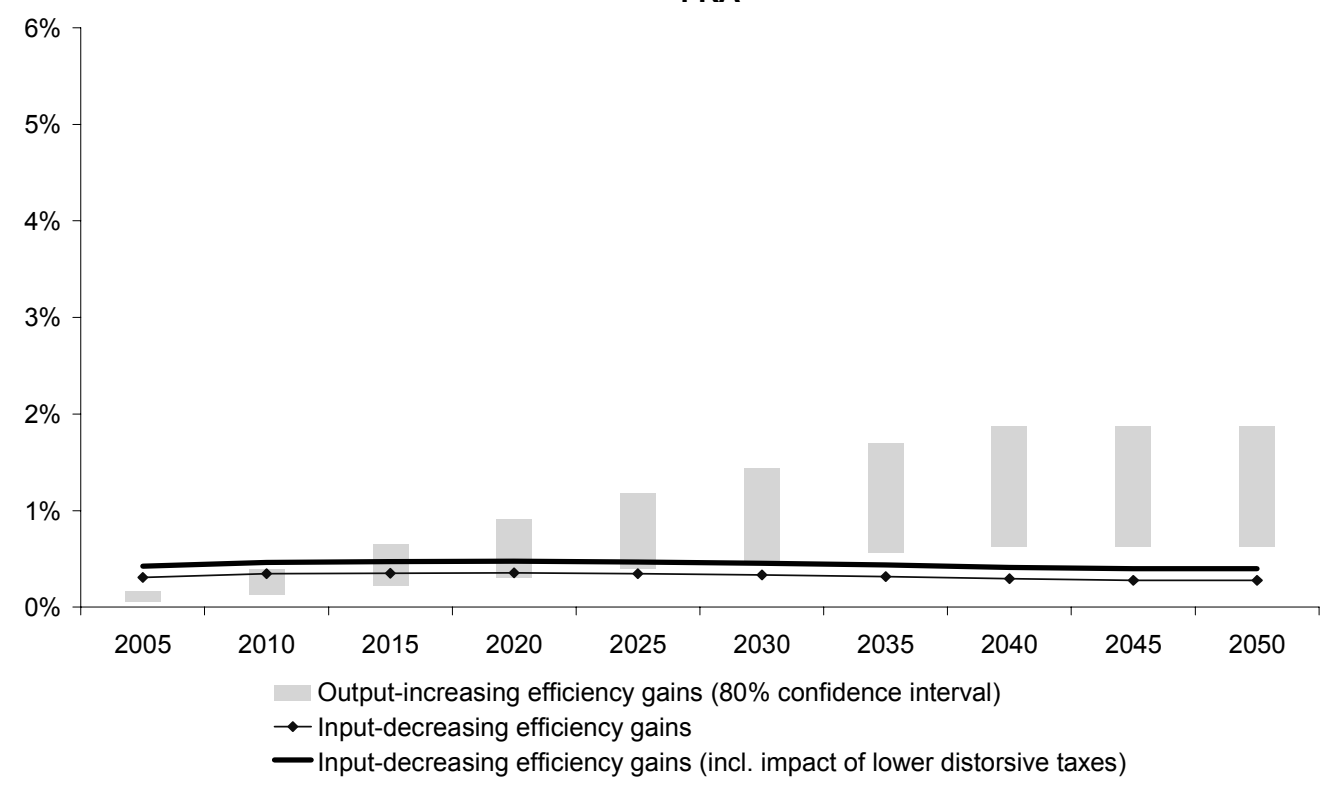




\section{BIBLIOGRAPHY}

Alesina, A., E. Glaeser and B. Sacerdote (2005), "Work and Leisure in the US and Europe: Why so Different?", Harvard Institute of Economic Research Discussion Paper, 2068.

Barro, R.J. (2001), “Human Capital and Growth”, American Economic Review, 91(2).

Barro, R. and J.-W. Lee (1993), "International Comparisons of Educational Attainment", Journal of Monetary Economics, 32 (3).

Barro, R. and J.-W. Lee (2001), "International Data on Educational Attainment: Updates and Implications", Oxford Economic Papers, 53 (3).

Bassanini, A. and S. Scarpetta (2001), "Does Human Capital Matter for Growth in OECD Countries? Evidence from Pooled Mean-group Estimates", OECD Economics Department Working Papers, No. 282.

Benhabib, J. and M.M. Spiegel (1994), "The Role of Human Capital in Economic Development: Evidence from Aggregate Cross-country Data." Journal of Monetary Economics 34 (2).

Beudaert, M. (2004), « Mesure des performances dans le domaine de l'éducation », paper presented to the 10th Colloque de comptabilité nationale organised by INSEE, January 2004 in Paris.

Cahuc, P. and A. Zylberberg (2001), Le marché du travail, De Boeck.

Collesi, D. (2000), "Volume Measures and Productivity Analysis for the Non-market Sector: the Italian Experience", Paper presented at the 15th. Meeting of the Voorburg Group on Services Statistics in Madrid, Session on non-market services.

De la Fuente, A. and R. Domenech (2000), "Human Capital in Growth Regressions: How Much Difference Does Data Quality Make?", manuscript, CSIC, Campus de la Universidad Autonoma de Barcelona.

De la Fuente, A. and A. Ciccone (2003), "Human Capital in a Global and Knowledge-based Economy," UFAE and IAE Working Papers, 562.03.

Englander, A.S. and A. Gurney (1994), "Medium-term Determinants of OECD Productivity", OECD Economic Studies, 22, pp. 49-109.

Gonand, F. (2005), "Assessing the Robustness of Demographic Projections in OECD Countries", OECD Economics Department Working Papers, No. 464.

Griliches, Z. (1997), "Education, Human Capital, and Growth: A Personal Perspective", Journal of Labor Economics, 15(1), S330-S344. 
Hanushek, E. and D.D. Kimko (2000), "Schooling, Labor Force Quality, and the Growth of Nations", American Economic Review, 90(5), pp. 1184-1208.

Hanushek, E. and L. Woessmann (2007), "The Role of School Improvement in Economic Development", NBER Working Paper, 12832.

Harmon, C., I. Walker and N. Westergaard-Nielsen (2003), "The Returns to Education: Microeconomics", Journal of Economic Surveys, 17(2).

Jorgenson, D.W., F.M. Gollop and B.M. Fraumeni (1987), Productivity and US Economic Growth, Harvard University Press, Cambridge.

Krueger, A.B. and M. Lindahl (1999), "Education for Growth in Sweden and the World", NBER Working Paper, 7190.

Maddison, A. (1991), Dynamic Forces in Capitalist Development, Oxford University Press, Oxford.

Mankiw, N.G., D. Romer and D. Weil (1992), "A Contribution to the Empirics of Economic Growth", Quarterly Journal of Economics, 107, 407-437.

Mincer, J. (1974), Schooling, Experience and Earnings, Columbia University Press, NY.

Montanino, A., B. Przywara and D. Young (2004), "Investment in Education: the Implications for Economic Growth and Public Finances", European Commission Directorate General for Economic and Financial Affaires Economic Papers, 217.

Nickell, S. (2004), "Employment and Taxes", Centre for Economic Performance Discussion Paper, 634, London School of Economics.

Nickell, S. and R. Layard (1999), "Labor Market Institutions and Economic Performance", in O. Aschenfelter and D. Card (eds.), Handbook of Labor Economics, Vol. 3, (Amsterdam, North Holland).

OECD (2006), Education at a Glance.

Prescott, E. (2004), "Why do Americans Work so Much More Than Europeans?", Federal Reserve Bank of Minneapolis Quarterly Review, 28(1).

Pritchett, L. (1996), “Where Has All the Education Gone?”, World Bank Policy Research Department Working Paper, 1581.

Romer, P. (1990), “Endogenous Technological Change”, Journal of Political Economy, 98(5).

Steedman, H. (1996), "Measuring the Quality of Educational Outputs: A Note", Centre for Economic Performance Discussion Paper, 302, London School of Economics.

Sutherland, D., I. Joumard, R. Price and C. Nicq (2007), "Performance Indicators for Public Spending Efficiency in Primary and Secondary Education", OECD Economics Department Working Papers, forthcoming.

UK Department for Education and Skills (2005), "Measuring Output from the Education System", mimeo, available at http://www.dfes.gov.uk/research/data/uploadfiles/RW45.pdf. 


\section{WORKING PAPERS}

The full series of Economics Department Working Papers can be consulted at www.oecd.org/eco/Working_Papers/

547. The impact on growth of higher efficiency of public spending on schools (March 2007) Frédéric Gonand

546. Performance indicators for public spending efficiency in primary and secondary education (February 2007) Douglas Sutherland, Robert Price, Isabelle Joumard and Chantal Nicq.

545. Monetary policy and macroeconomic stability in Latin America: the cases of Brazil, Chile, Colombia and Mexico

(February 2007) Luiz de Mello and Diego Moccero

544. The Brazilian "tax war": the case of value-added tax competition among the states (February 2007) Luiz de Mello

543. Public spending efficiency: institutional indicators in primary and secondary education (January 2007) Frédéric Gonand, Isabelle Joumard and Robert Price

542. Enhancing turkey's growth prospects by improving formal sector business conditions (January 2007) Rauf Gönenç, Willi Leibfritz, Gökhan Yilmaz

541. Fiscal relations across levels of government in Australia (January 2007) Vassiliki Koutsogeorgopoulou

540. Russian manufacturing and the threat of 'Dutch Disease': A comparision of competitiveness developments in Russia and Ukrainian industry

(January 2007) Rudiger Ahrend, Donato de Rosa and William Tompson

539. Stimulating innovation in Russia: The role of institutions and policies (January 2007) Christian Gianella and William Tompson

538. Healthcare reform in Russia: problems and prospects (January 2007) William Tompson

537. A golden rule for Russia? How a rule-based fiscal policy can allow a smooth adjustment to the new terms of trade

(January 2007) Christian Gianella

536. From "clientelism" to a "client-centred orientation"? The challenge of public administration reform in Russia (January 2007) William Tompson

535. Has the rise in debt made households more vulnerable?

(December 2006) Nathalie Girouard, Mike Kennedy and Christophe André

534. Social security reform in Brazil: Achievements and remaining challenges (December 2006) Fabio Giambiagi and Luiz de Mello

533. Improving labour utilisation in Brazil (December 2006) Luiz de Mello, Naércio Menezes Filho and Luiz G. Scorzafave

532. Boosting innovation performance in Brazil

(December 2006) Carlos H. de Brito Cruz and Luiz de Mello 


\section{ECO/WKP(2007)7}

531. Consolidating macroeconomic adjustment in Brazil

(December 2006) Luiz de Mello and Diego Moccero

530. Product market regulation in the non-manufacturing sectors of OECD countries: Measurement and highlights (December 2006) Paul Conway and Giuseppe Nicoletti

529. The Turkish pension system: further reforms to help solve the informality problem (November 2006) Anne-Marie Brook and Edward Whitehouse

528. Policies to improve Turkey's resilience to financial market shocks (November 2006) Anne-Marie Brook.

527. Upgrading Japan's innovation system to sustain economic growth (November 2006 Randall S. Jones and Tadashi Yokoyama

526. Strengthening the integration of Japan in the world economy to benefit more fully from globalisation (November 2006) Randall S. Jones and Taesik Yoon

525. OECD's FDI regulatory restrictiveness index: Revision and extension to more economies (November 2006) Sven Blöndal and Alain de Serres

524. Globalisation and inflation in the OECD economies (November 2006) Nigel Pain, Isabell Koske and Marte Sollie

523. Identifying determinants of Germany's international price competitiveness - A structural VAR approach (November 2006) Martin Meurers

522. Short-term pain for long-term gain: the impact of structural reform on fiscal outcomes in EMU (November 2006) Paul van den Noord and Boris Cournède

521. Interactions between monetary and fiscal policy: How monetary conditions affect fiscal consolidation (November 2006) Rudiger Ahrend, Pietro Catte and Robert Price

520. Restoring fiscal sustainability in the Euro Area: raise taxes or curb spending? (October 2006) Boris Cournède and Frédéric Gonand

519. Should Measures of Fiscal Stance be Adjusted for Terms of Trade Effects (October 2006) David Turner

518. Monetary policy and inflation expectations in Latin America: Long-run effects and volatility spillovers (October 2006) Luiz de Mello and Diego Moccero

517. Social safety nets and structural adjustment (September 2006) Paul van den Noord, Nathalie Girouard and Christophe André

516. Adapting the Icelandic education system to a changing environment (September 2006) Hannes Suppanz

515. Forecasting monthly GDP for Canada (September 2006) Annabelle Mourougane

514. Finland's housing market: reducing risks and improving policies (September 2006) Laura Vartia

513. The Danish housing market: Less subsidy and more flexibility (September 2006) Espen Erlandsen, Jens Lundsgaard and Felix Huefner 